\title{
Stratigraphic interpretation of loess in the marginal zone of the Dnieper I ice sheet and the evolution of its landscape after deglaciation (Dnieper Upland, Ukraine)
}

\author{
Maryna KOMAR ${ }^{1,2}$, Maria $Ł A N C Z O N T^{3}$, Stanisław FEDOROWICZ ${ }^{4}$, Petro GOZHIK ${ }^{1}$, \\ Przemysław MROCZEK ${ }^{3, *}$ and Andryi BOGUCKI ${ }^{5}$
}

1 National Academy of Sciences of Ukraine, Institute of Geological Sciences, Gonchara 55B, 01601 Kyiv, Ukraine

2 National Academy of Sciences of Ukraine, National Museum of Natural History, 15 Bohdan Khmelnitsky, Kyiv, 01 601, Ukraine

3 Maria Curie-Skłodowska University, Faculty of Earth Sciences and Spatial Management, Al. Kraśnicka 2d, 20-718 Lublin, Poland

4 University of Gdańsk, Institute of Geography, Department of Geomorphology and Quaternary Geology, ul. Ba yńskiego 4, 80-950 Gdańsk, Poland

5 Ivan Franko National University, Department of Geomorphology and Palaeogeography, Doroshenka 41, 79000 Lviv, Ukraine

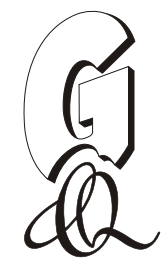

Komar, M., Łanczont, M., Fedorowicz, S., Gozhik, P., Mroczek, P., Bogucki, A., 2018. Stratigraphic interpretation of loess in the marginal zone of the Dnieper I ice sheet and the evolution of its landscape after deglaciation (Dnieper Upland, Ukraine). Geological Quarterly, 62 (3): 536-552, doi: 10.7306/gq.1434

Litho-, pedo- and palynological analyses constrained by radiometric dating of two loess-palaeosol sequences, Nahirne and Velyka Andrusivka, exposed in a cliff at the eastern edge of the Dnieper Upland, Ukraine, document regional environmental changes in the western marginal zone of the Dnieper lobe. The postglacial loess sedimentation cycle was initiated during MIS 8, immediately after the ice sheet recession. On the basis of palaeorelief analysis, subsequent morphogenetic stages of the original postglacial relief, associated with the modifying and masking role of the loess, and destructive slope processes were reconstructed. Periglacial steppe with consistently present scattered trees formed the Pleistocene landscape in the Middle Dniester area during the last three glacial periods. In such an environment, the following loess beds, correlated with marine isotope stages (MIS), were deposited: Dnieper $(d n)$ - MIS 8, Tyasmyn (ts) - MIS 6, Uday (ud) - MIS 4 and Bug $(b g)-$ MIS 2. During the last two warm periods: Kaydaky $(k d)-$ MIS 7 and Pryluky $(p /)-M I S 5$, the landscape was not fully forested. As a result, the individual palynological features of these soils show a diverse character. The TL and OSL dates form a sequence with numerous inversions that are difficult to interpret. Although these data do not significantly influence the interpretation, they show that: 1) there are loesses that undoubtedly formed after the maximum extent of the ice sheet by short-distance transport of dust material from local fresh glacial deposits and the underlying Paleogene rocks; 2) date distortions result from the activities of an exceptionally rich pedofauna that has contaminated the material not only in the soil sections of the profile but also in the adjacent loess. It is possible to delimit a few stages of pedofaunal activity in each of the soil units.

Key words: loess, palaeosol, Dnieper, Pleistocene, palaeogeography, palynology, luminescence dating.

\section{INTRODUCTION}

The main aim of this study is reconstruction of post-glacial Pleistocene landscape evolution in the vicinity of territory currently occupied by the Kremenchuk Reservoir in the Middle Dnieper River Basin, Ukraine. The Middle Dnieper area is traditionally considered to be representative of and crucial for the foundation of Ukraine's loess stratigraphy scheme (Veklitch,

* Corresponding author, e-mail: loess@poczta.umcs.lublin.pl Received: January 2, 2018; accepted: May 9, 2018; first published online: October 25, 2018
1993). The loess succession of this region consists of more than10 loess-palaeosol units (Gozhik et al., 2001a) and the glacial till of the Dnieper I Glaciation is the key stratigraphic marker within them (Matoshko, 2004, 2011a, b; Gozhik, 2008). The Dnieper I ice sheet covered this area during MIS 8 (Gozhik and Chugunny, 1981; Gozhik et al., 2012; Gozhik, 2000, 2008; Lindner et al., 2004; Matoshko, 2004, 2011a), reaching its maximum extent in the southern vicinity of the town of Dnipro (Fig. $1 \mathrm{~A})$. The deposits of the Dnieper I Glaciation form a cover $6-12 \mathrm{~m}$ thick on average in its marginal zone, including the area of the Kremenchuk Reservoir. They overlie the older Pleistocene deposits with erosional or glaciotectonic/glaciodynamic contact (Matoshko, 1999, 2011b). The loess marked as $d n$ (Dnieper loess unit) was deposited immediately after the ice sheet retreat (Gozhik et al., 1995, 2001b, d). On the high and 

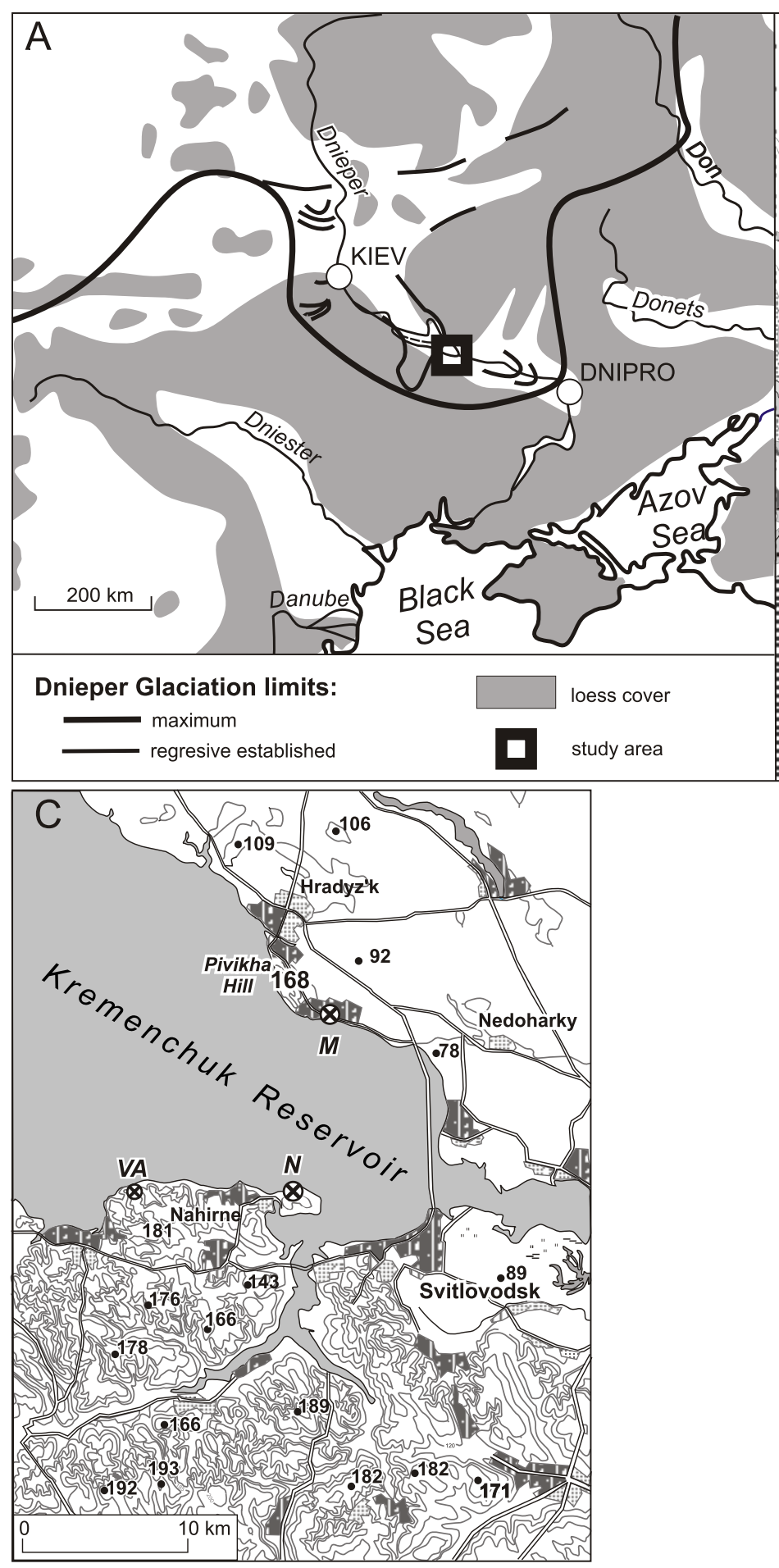

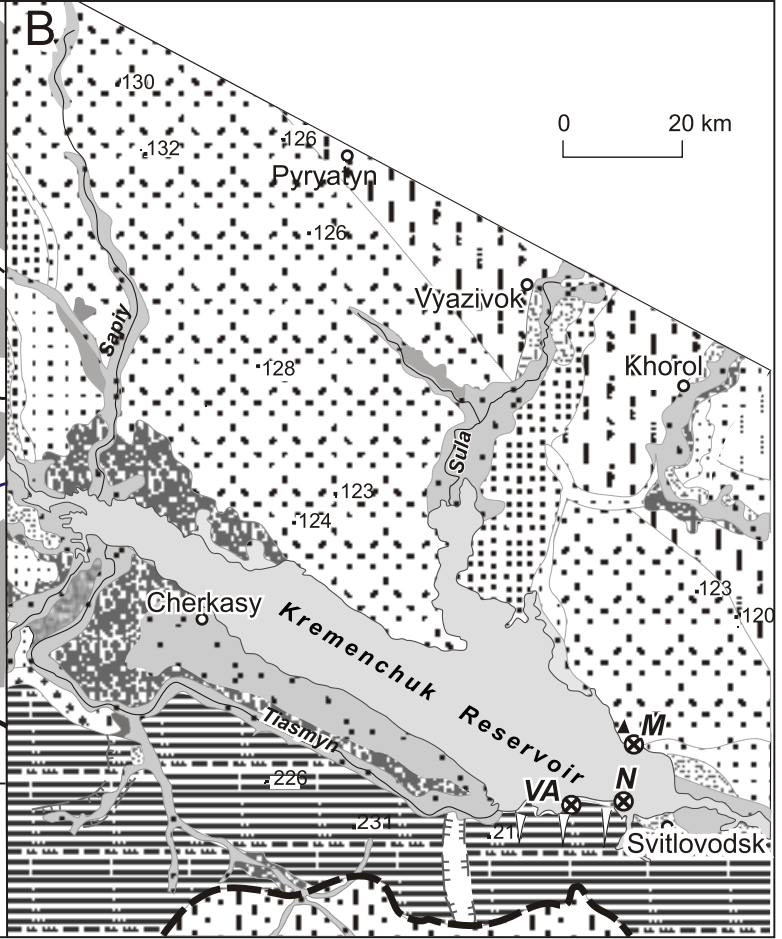

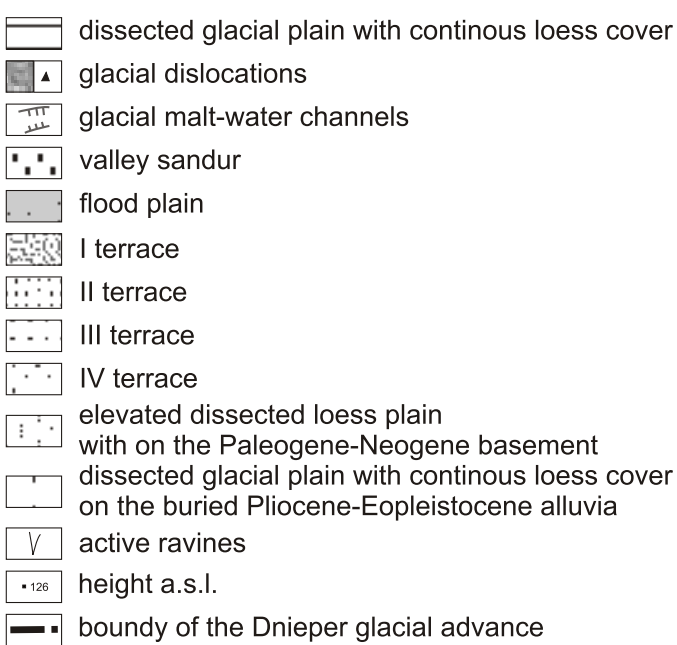

\section{Fig. 1. Location of the area investigated}

A - range of the Dnieper Glaciation according to Matoshko (2011a) and Gozhik et al. (2012) against the distribution of loess covers in Central Ukraine; B - geological elements and geomorphology of the Kremenchuk Reservoir after Gozhik et al. (2014, supplemented and modified); C - topographical sketch of the lower part of the Kremenchuk Reservoir near Svitlovodsk; investigated loess sites: M - Maksymivka, N Nahirne, VA - Velyka Andrusivka

steep, actively undercut edges of the Kremenchuk Reservoir (Fig. 1B, C) this loess cover is exposed in numerous places.

The nature of the loess cover was dictated by the diversity of the fresh postglacial relief. Due to differences in the geometry of the surface under the ice - on the left side of the river it was the flat Dnieper Lowland, and the right of the valley comprised the plateau of the Dnieper Upland of varied relief and elevations of $\geq 200 \mathrm{~m}$ and topographic relief of $60-80 \mathrm{~m}$ - the ice sheet advanced towards the SE along the Dnieper Valley at different speeds on either side of the ice lobe. The advance was faster 
along the left part of the lobe across the surface of the present terrace IV and older terraces. The almost flat attitude of the basal till indicates that the ice sheet did not show erosive capacities, except for in the area of Pivikha Hill (Goretsky, 1970; Matoshko and Chugunny, 1993; Gozhik et al., 2001a, b, c). Advance of the right side of the ice lobe was slowed by the hilly plateau. In places the bedrock was eroded and deformed, small ice-rafts created, and the lowered mouths of the tributary valleys were remodelled. As a result of these conditions, glacial tills on both Kremenchuk Reservoir sides are found at an elevation difference of over $100 \mathrm{~m}$. Consequently, the morphological and hypsometric situation of the loess deposits is also different (Gozhik, 2008). Their detailed characteristics are shown for the left bank at the Maksymivka site $\left(49^{\circ} 10^{\prime} 44^{\prime \prime} \mathrm{N}, 33^{\circ} 10^{\prime} 13^{\prime \prime} \mathrm{E}\right)$, where the loess-soil sequences show a generally horizontal or slightly inclined attitude and continuous course (Komar et al., 2012; Gozhik et al., 2014). Located almost opposite on the right shore of the reservoir, there are two sites: the main site of Nahirne $\left(49^{\circ} 4^{\prime} 59.41^{\prime \prime} \mathrm{N} ; 33^{\circ} 7^{\prime} 20.03^{\prime \prime} \mathrm{E}\right)$ and the supplementary site of Velyka Andrusivka (495'14.21"N; 3259'41.93"E) (Fig. $1 \mathrm{~B}, \mathrm{C})$, where the complex layout of the loess-soil horizons forming loess-palaeosol chronosequences is visible in the discontinuity of their course and thinning out on elevated areas. Systems of such inclined palaeocatenas are emphasised by the colour difference between the past and recent soils. Among them a thick succession of interglacial Kaydaky fossil soils, visible at the bottom of an active cliff in Nahirne village, played a significance role in the regional stratigraphy (Putevoditel..., 1999; Gozhik et al., 2001b, d; Łanczont et al., 2013a). Observations from subsequent years (2001-2010) documented its spatial variability as the cliff retreated but this section has not yet been extensively studied. The problems of determining the stratigraphy and age of the loess in the Nahirne profile encouraged a Ukrainian-Polish team to study in more detail the age and evolution of these deposits. The results obtained were further analysed in relation to the supporting materials, especially the results of palaeogeographic studies of the adjacent geological profile at Velyka Andrusivka (Komar et al., 2004, 2005). This gave rise to consideration of the conditions shaping the natural environment on the right bank of the Dnieper River Valley after the Dnieper I ice sheet retreated. The regional scale is allowed by comparison with the Maksymivka profile.

\section{GEOLOGICAL AND GEOMORPHOLOGICAL SETTING}

The Middle Dnieper is an important border between the geographical loess regions of the Dnieper Upland (Nahirne and Velyka Andrusivka profiles) to the west and the Dnieper Lowland (Maksymivka profile) to the east. The Dnieper outlines the border of the forest-steppe zone with the steppe. Presently, it is the area representing a temperate climate with continental features, which is indicated by a high annual range of mean temperature of almost $25.5^{\circ} \mathrm{C}$ and average annual precipitation $<540$ mm (Wróbel and Mrugała, 2001; Kocsis et al., 2008). The dominant type of soil comprises chernozems represented by variations: podsolised, typical and ordinary ones, which alternate westwards with Albeluvisols and Humic Gleysols (Grunty-Ukraina, 1997; Soil Atlas of Europe, 2005).
The profiles at Nahirne and Velyka Andrusivka are situated within the Shevchenko eroded palaeovalley (Goretsky, 1970; Matoshko and Chugunny, 1993). There are glacial deposits here representing basal till and fluvioglacial sediments (Gozhik et al., 2001b, d; see Matoshko 2011a: fig. 31.4, p. 410). On the adjacent plateau fragments, glacial deposits are positioned 90-110 m higher. In the direction of Nahirne, the high edge of the reservoir shore, dissected by young gullies, is built of Pliocene and old Quaternary deposits, locally with glacial tills or redeposited erratics. Rarely, ice-rafted Paleogene deposits are also found here.

The main element of the Nahirne relief is a glacial-glaciofluvial plain with a continuous loess cover (211 $\mathrm{m}$ a.s.I.), which is deeply dissected by a system of young active gullies and gorges (Fig. 1B, C). From north to south, or near that direction, the plain is crossed by subglacial meltwater channels. In the north the glacial-glaciofluvial plain adjoins directly the Kremenchuk Reservoir's shore, or it is separated from it by a narrow discontinuous strip of the 1st terrace. The southern limit is defined by the limit of the Dnieper ice sheet advance; farther, there extends an elevated dissected loess plain covering the Paleogene-Neogene basement (Gozhik et al., 2001b, d). The fluvial relief of the research area is represented by the Pleistocene 1st and 2 nd terraces of the Dnieper to the west of Chygryn, as well as the 1st terrace in the valley of the Tyasmyn River. The 2nd terrace with a width of $6-7 \mathrm{~km}$ is $20 \mathrm{~m}$ above the reservoir water level and $35 \mathrm{~m}$ above the Tyasmyn Valley.

\section{METHODS}

Litho-pedostratigraphic units (Nahirne site). Field research at the Nahirne loess site was conducted in 2010. The profile analysed consists of three sections separated from each other but spatially correlated (Fig. 2A). The exposures were described in detail in the field, delimiting loess units and soil of different stratigraphic rank according to palaeopedological criteria. The three sections analysed are aggregated in Figures 3 and 4 , including a simplified description of the lithological and stratigraphic characteristics of the profile, in relation to the formal scheme of Ukrainian loess stratigraphy (Veklitch, 1993). The material for lithological analyses was derived directly from the samples prepared for dating. The sediment particle size distribution was determined by laser diffraction using a Mastersizer 2000 HydroG analyser measuring up to $2000 \mu \mathrm{m}$ diameter in the laboratory in Lublin. Based on particle size distribution, selected granulometric parameters were calculated (Appendix $1^{*}$ ), i.e. mean grain size $(\mathrm{Mz})$ and sorting (standard deviation, $\delta)$. The percentages of carbonates (Scheibler method) and loss on ignition were determined in the laboratory in Gdańsk to determine the content of organic matter. Eight monoliths were also collected to determine the micromorphological characteristics of the soil horizons selected (Appendix 1; Fig. 5) according to the method used by Mroczek (e.g., Mroczek, 2008, 2013; Fedorowicz et al., 2013; Gozhik et al., 2014). Their location coincided with the samples for dating (Fig. 4). An additional feature identified in the field and verified in the laboratory was the colour, tested on wet samples according to the Munsell colour scale (Revised Standard Soil Color Charts, 1970). 

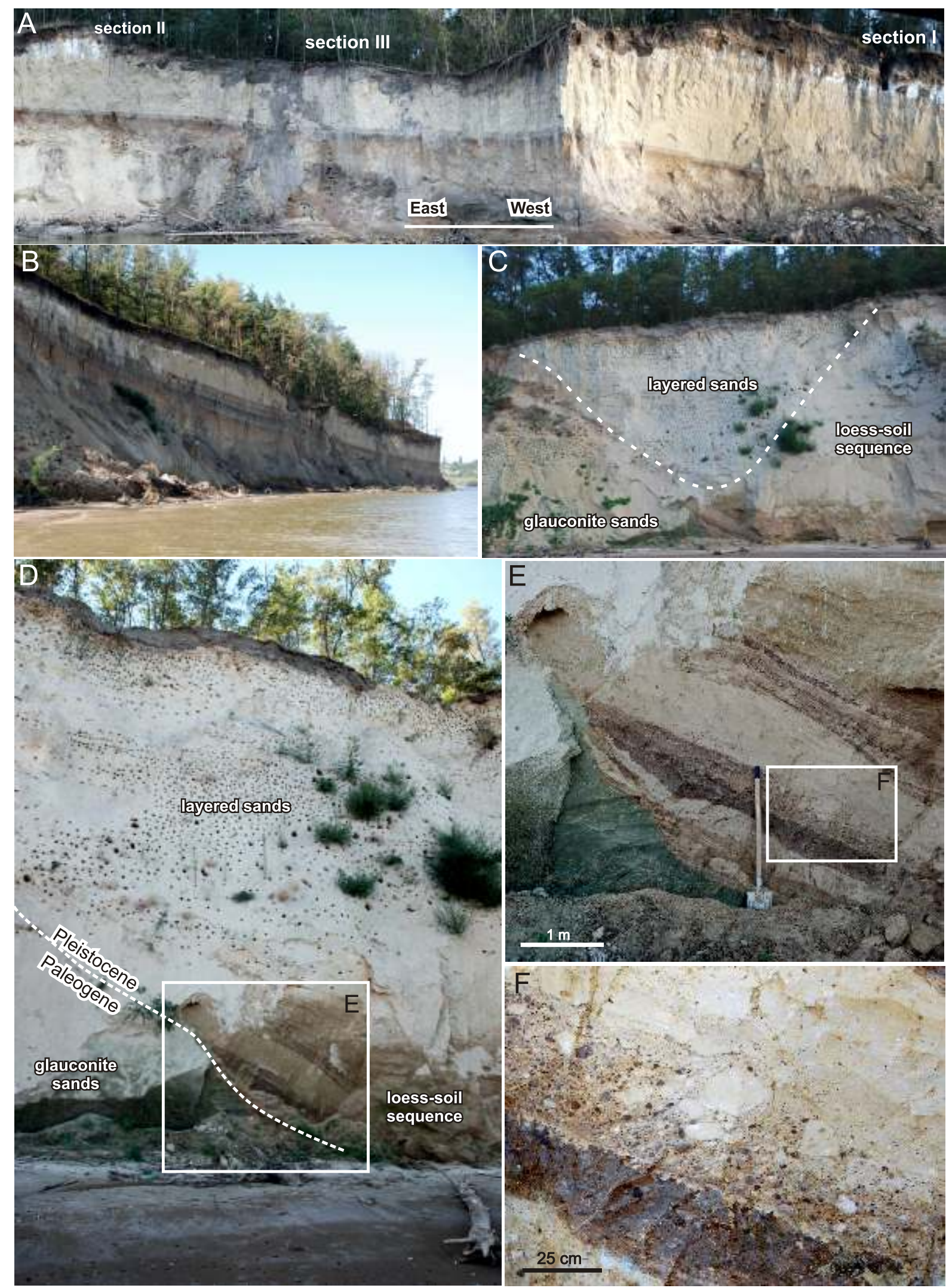

Fig. 2. Main geological elements of the cliff at Nahirne

A, B - systems of fossil valleys/basins infilled with loess and the sections investigated (I-III); C - small fossil valley infilled with layered sands; D - steep slope built of Paleogene sands and old palaeosol aggregates; E, F - bottom of the cliff built of soil material (photos M. Łanczont) 


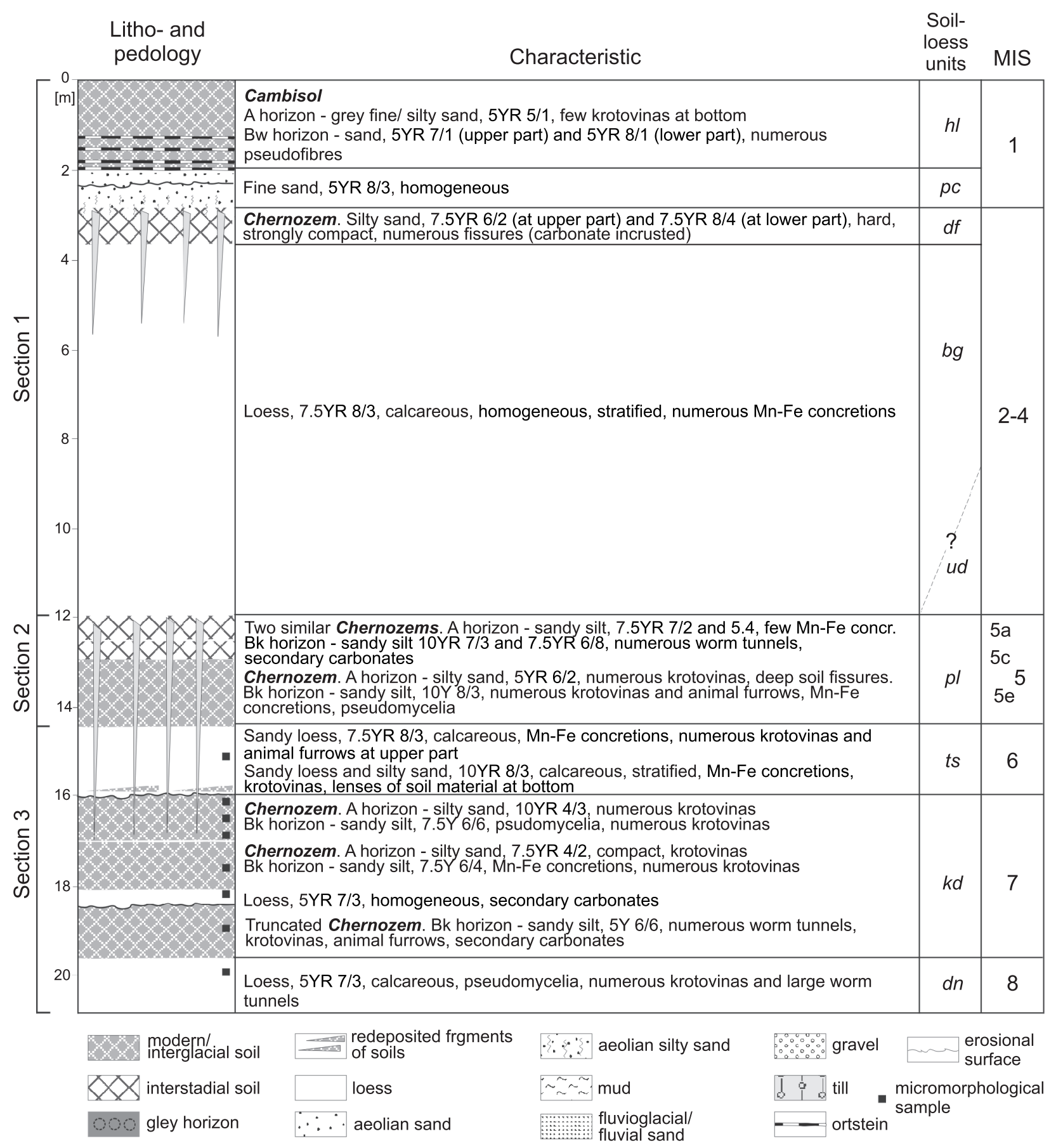

Fig. 3. Simplified litho- and pedological characteristics as well as stratigraphic interpretation of the Nahirne profile

For other explanations see text

Radiometric dating (Nahirne site). A total of 36 dates were obtained, of which 35 were luminescence dates with one radiocarbon date. Twenty luminescence dates were obtained with the thermoluminescence (TL) method, and 15 with the OSL-SAR method (Łanczont et al., 2013a). The TL was performed by the multiple-aliquot regenerative technique (Wintle and Prószyńska, 1983) for quartz fraction 80-100 $\mu \mathrm{m}$. A detailed description of the measurement methods and equipment is given in Fedorowicz et al. (2013). The OSL dates were made for quartz fractions 90-125 $\mu \mathrm{m}$. Appendixes 2 and 3 contain the results: dose rate, equivalent dose and age. Appendix 3 also contains information on the number of modalities in the OSL date distribution and the age range of individual dates. The dates were referenced to the regional chronostratigraphic correlation for the last $270 \mathrm{ky}$ in Europe north of the Mediterranean, based on the chronostratigraphic calibration of the oxygen isotope stages in marine successions (Cohen and Gibbard, 2011).

Mineralogical analysis (Velyka Andrusivka). Mineralogical analysis of samples from the loess-soil sequence in the Velyka Andrusivka was performed for light and heavy fractions (0.25-0.01 mm grain size; Komar et al., 2005). 


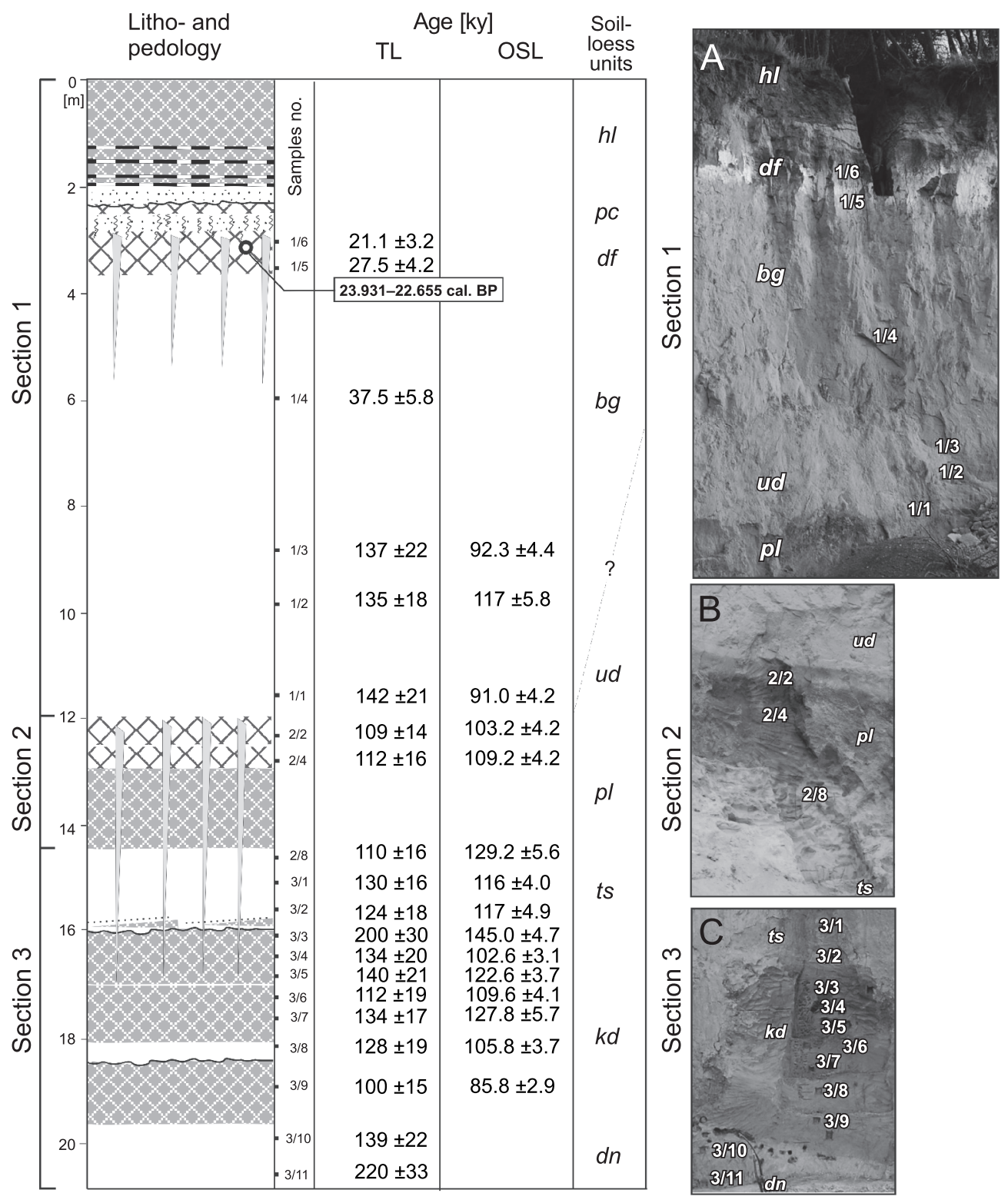

Fig. 4. Results of radiometric dating of the Nahirne profile

Photographs A-C represent exposures 1-3 together with the location of the samples and description of the stratigraphic loess and soil units; for explanations see Figure 3

Pollen analysis (Velyka Andrusivka). Samples were taken from the profile section at 12.5-22.6 m, from the layers: ud (2 samples), pl (3), ts (2), kd (5) and $d n$ (3) (Komar et al., $2004,2005,2009)$. The method of chemical preparation is described in detail in Komar et al. (2009). The histogram (see Fig. 7) shows the main groups of plants, i.e. trees, shrubs, dwarf shrubs, herbaceous plants as well as spores by families and genera. Concentration of pollen grains was generally good and amounted to $>200$ grains in almost every slide. If it was too low, the presence of an individual species was indicated by the "+" sign in the histogram. The reconstruction of the pollen succession was based on local pollen assemblage zones (L PAZ). Using the method of plant indicator species - given by Komar et al. (2009) - winter (MTC) and summer (MTW) palaeotemperatures were determined in a given L PAZ (Fig. 6).

\section{RESULTS}

\section{NAHIRNE SITE}

Litho-pedostratigraphic units. The geological structure of the eroded cliff (Fig. 2A, B), with a height of over 20 m, was investigated along its extent. From this analysis, it is clear that the visibly older deposits, disturbed by deforming ice sheet activity, are located near younger loess horizons which show features of sedimentation or denudation-erosion contact (Fig. 2C-E). Thus, in the western part of the cliff section analysed there is a steeply inclined package of Oligocene strongly compressed glauconitic sands (the Kharkiv "series"), covered by remnants of the redeposited old soil forming mylonitised layers parallel 

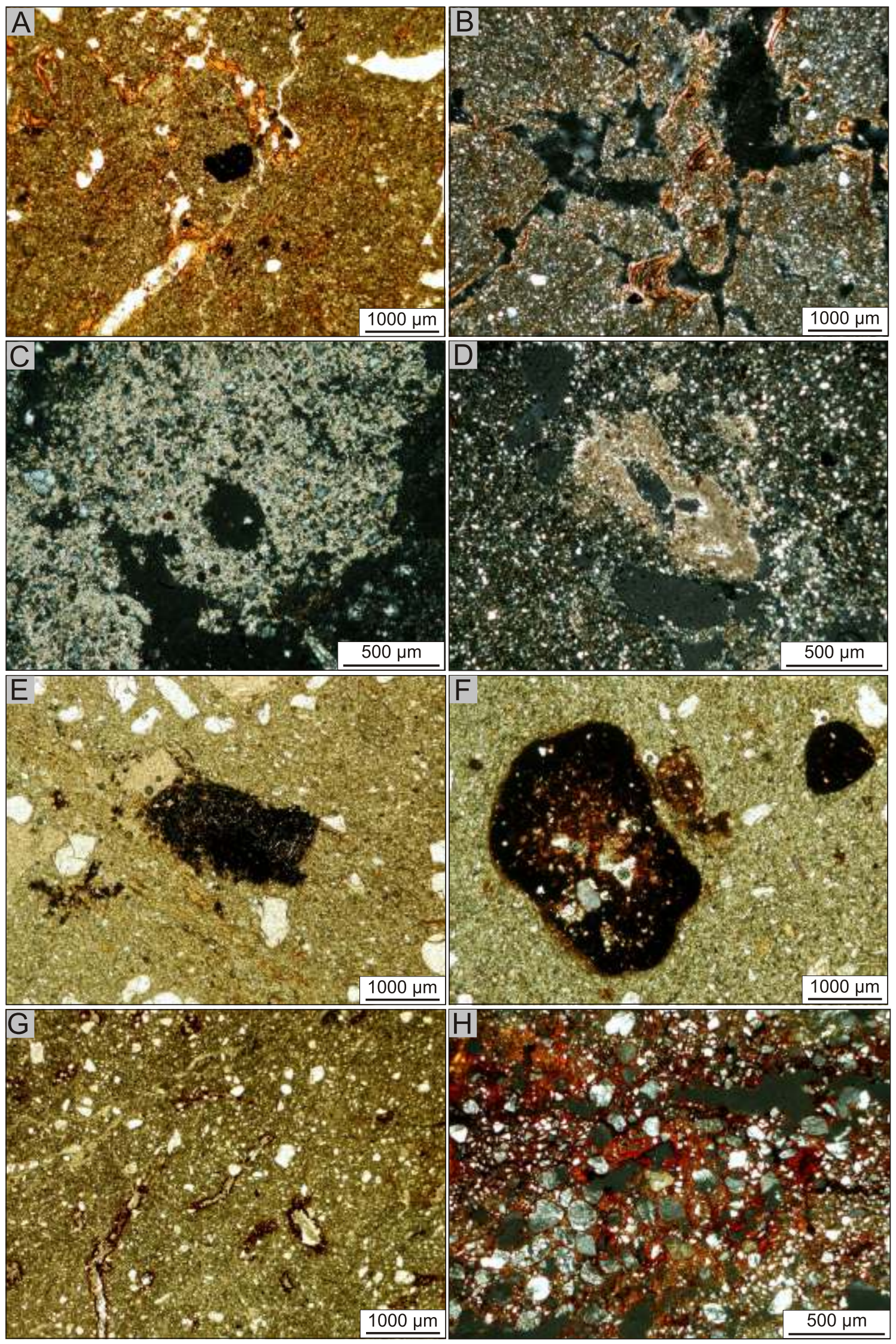

Fig. 5. Examples of micromorphological features analysed in the Nahirne profile

A, B - disrupted clay coatings (sample N3/4 and 3/7 respectively); C - micritic concentration (N3/10); D - secondary channel hypocoating (N3/3); $\mathbf{E}$ - irregular Fe-Mn nodules (N3/1); F - oval Fe-Mn nodules (N3/1); G - ferruginous channel hypocoatings (N2/2); $\mathbf{H}$ - ferruginous background (N2/4) 


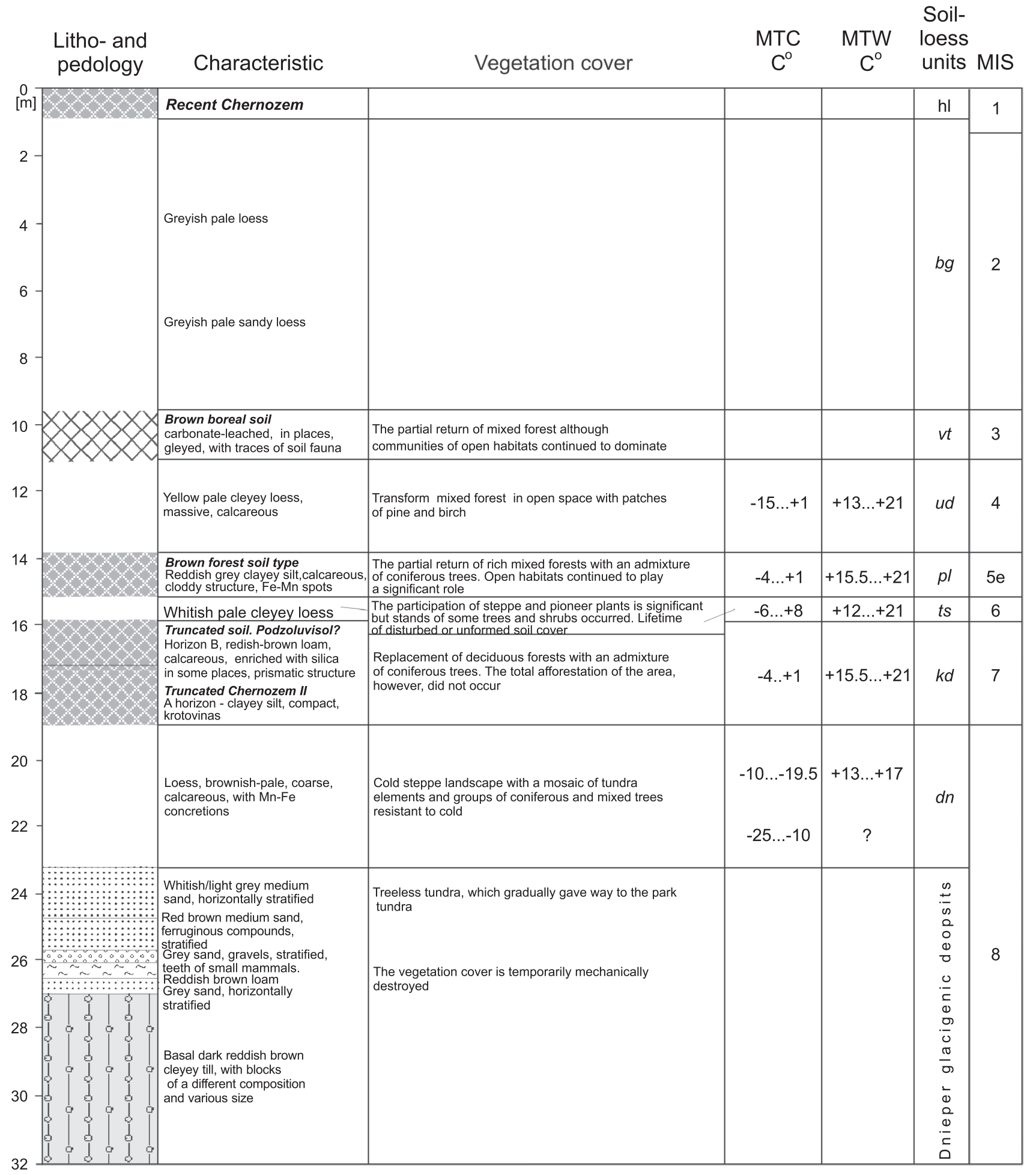

Fig. 6. Velyka Andrusivka profile according to Komar et al. (2005, modified)

For explanation see Figure 3

with the contact plane and composed of large prismatic clay soil and loess aggregates (Fig. 2E, F).

In the eastern part of the cliff section analysed, where loesses were surveyed, a transverse intersection reveals several generations of fossilised basin-like valleys. From their layout it follows that the loess sedimentation after each cycle par- tially masked the former relief while erosion processes remodelled it, which resulted in making the forms more subdued and shifting their axes. In the profile studied the pedogenetically transformed deposits constitute the dominant part; these are two intraloess fossil soil successions of interglacial rank: units Kaydaky ( $k d$; MIS 7) and Pryluky ( $p l$, MIS 5). The Dnieper 


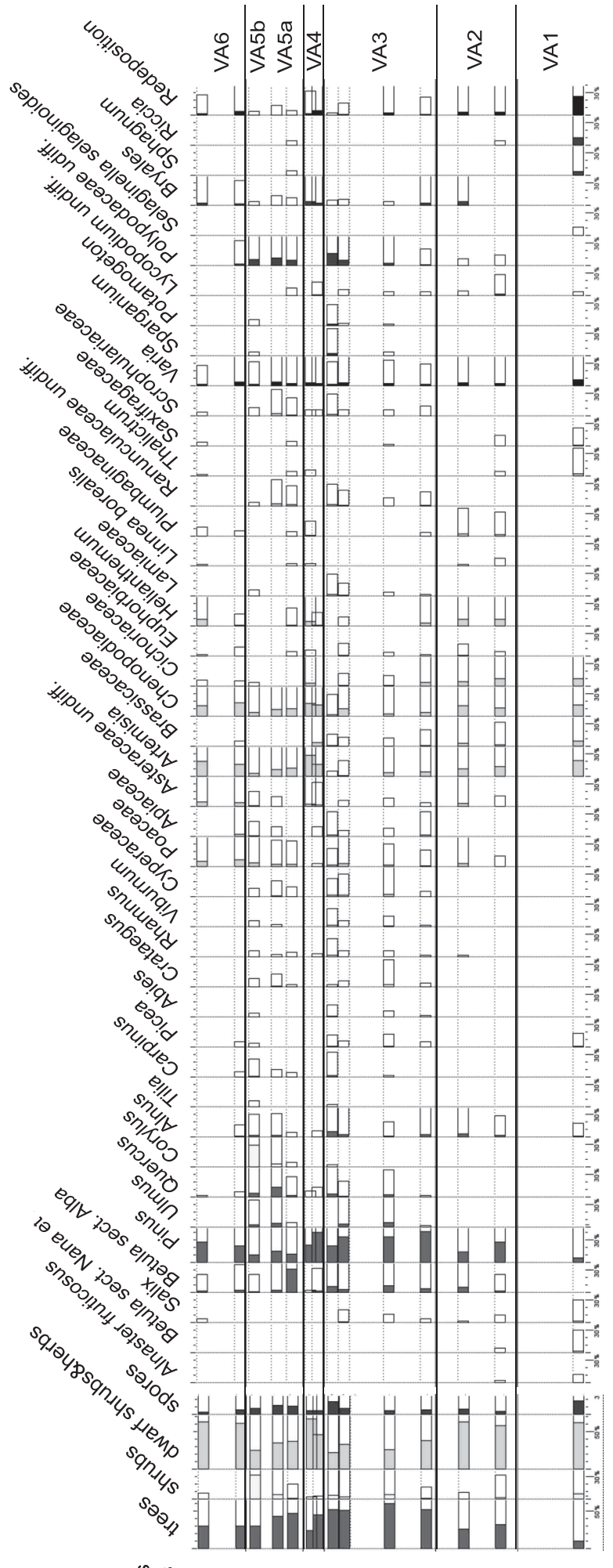

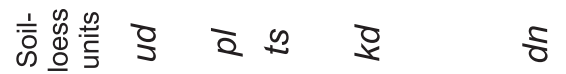

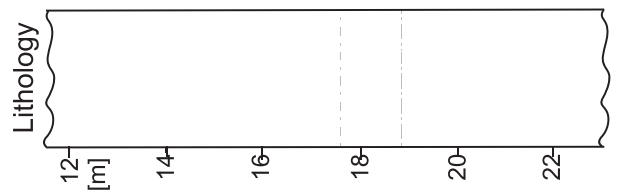

loess ( $d n$; MIS 8 ) is the oldest stratigraphic unit in the Nahirne profile (Figs. 3 and 4). It is found in the lower part of section 2 (where ts loess overlies directly $d n$ loess) and in section 3 (Fig. 4C). The thickness of $d n$ is unknown - it was exposed in a layer of up to $1 \mathrm{~m}$ (at the water level in the reservoir). In terms of particle size, the top unit of these loesses has a mean particle size $(\mathrm{Mz})$ of $22.6 \mu \mathrm{m}$ and poor sorting. These deposits are relatively rich in carbonates (10.8\%) and organic matter $(2.9 \%)$. As regards micromorphology the dominant features are secondary forms of carbonate development commonly filling up free spaces (Fig. 5C).

Samples N3/11 and N3/10 were collected from the Dniepr loess $(d n)$ at a distance of $0.6 \mathrm{~m}$. They were dated only by the TL method, and the dates obtained differ significantly from each other. The bottom date was $220 \pm 33 \mathrm{ka}$, while the upper one was $139 \pm 22$ ka (Fig. 4), both dates being younger than the formation of the Dnieper loess ( $d n$; see Fig. 8). The equivalent doses of both samples differ significantly (Appendix 1), indicating a large heterogeneity of the Dnieper loess.

The Kaydaky unit $(\mathrm{Mz}=21.9-40.1 \mu \mathrm{m} ; \sigma=$ 1.7-1.9) consists of three soil subunits and one $m$ loess (Fig. 4C). Its surface is inclined and in the western part it goes to and below the water level. The entire sequence has low and somewhat vari\& able carbonate content $(0.8-1.5 \%)$ and a signifiक cant content of organic matter $(2.2-3.2 \%)$. The 을 truncated oldest soil represented only by horizon $\frac{\pi}{\frac{\pi}{\sigma}} \mathrm{B}(0.6 \mathrm{~m}$ thick$)$ is almost entirely transformed by soil fauna. The intensity of animal activity is seen as pseudomorphs of small tunnels after worms, ¿े filled with reddish brown dust and fossil animal burrows filled with loess, humus material and horizon Bk material (Fig. 4). At the bottom of the horizon and in the Dnieper loess $(d n)$ below, there are particularly numerous krotovinas and large fossil burrows (diameter $\geq 15 \mathrm{~cm}$ ). These are crossed by worm tunnels, which in this case are a younger generation of zoogenic forms. Intra-soil, very fine-grained loess $(0.85 \mathrm{~m}$ thick; $\mathrm{Mz}=21.9 \mu \mathrm{m}$, with very poor sorting, $\mathrm{CaCO}_{3}=1.5 \%$ ) separates this soil from the above two superimposed soils of chernozem type (1 and $1.15 \mathrm{~m}$ thick respectively), each of which is composed of an intensely dark humus horizon and a light brown Bk illuvial horizon with clay microfeatures (Fig. 5A, B) and numerous secondary carbonates mainly formed as calcite intratunnel infillings (Fig. 5D; Appendix 1). The youngest soil underlies soil colluvia which originated from its destruction in higher parts of the terrain.

Further samples from N3/9 to N3/3 were collected from the $k d$ soil material. All the TL dates are in the range of 100 to $140 \mathrm{ka}$, while the oldest date in the set is $200 \pm 30 \mathrm{ky}$ (sample N3/3). The same sample also has the oldest date in the OSL date set $(145.0 \pm 4.7 \mathrm{ka})$, while the others oscillate between 85.9 and $127.8 \mathrm{ky}$ (Appendix 2). Besides 


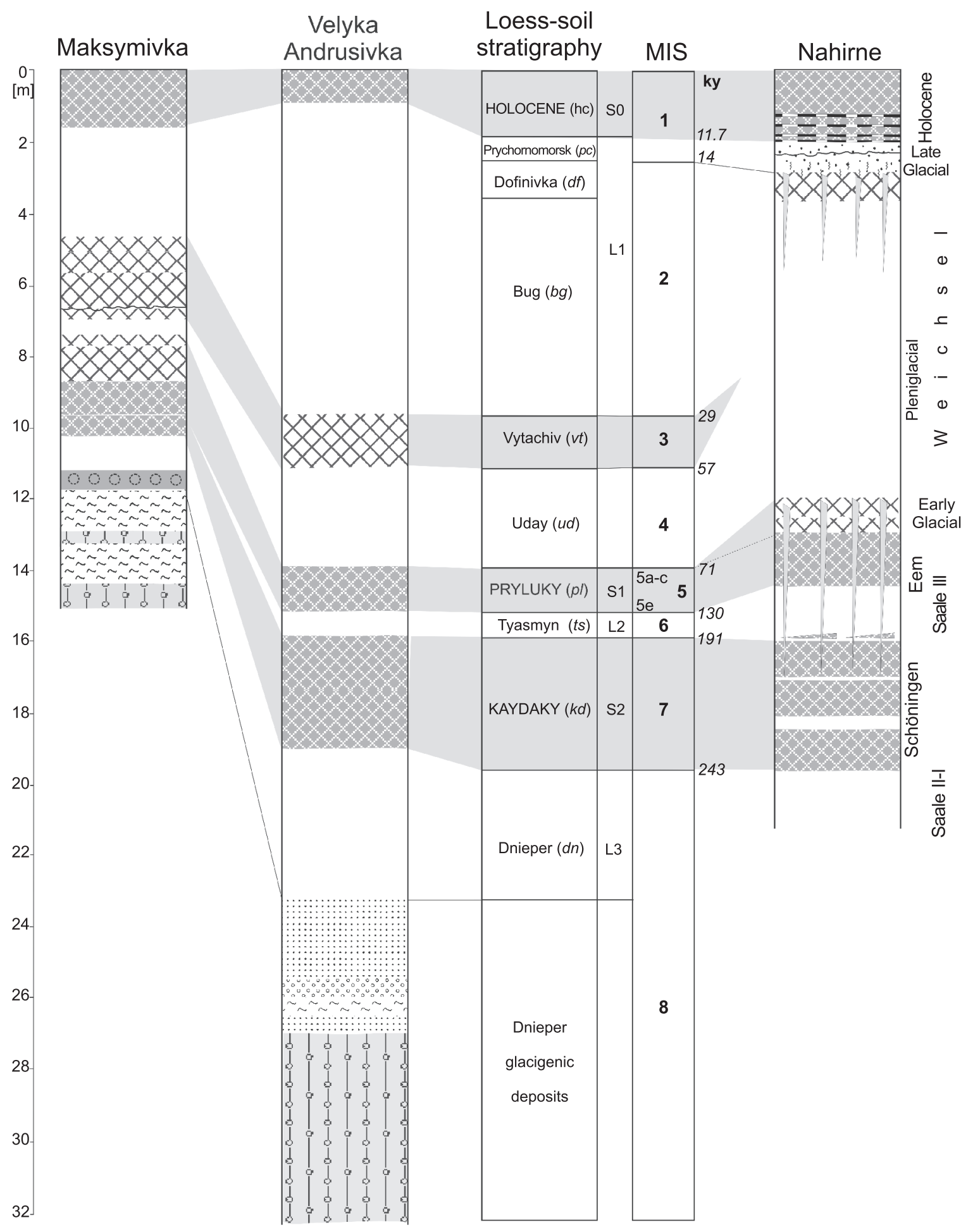

Fig. 8. Stratigraphy and correlation of the Nahirne, Velyka Andrusivka and Maksymivka profiles located in the marginal zone of the Dnieper I Glaciation

For explanations see Figure 3

the date of sample N3/3, the range of the single OSL dates also does not exceed $175 \mathrm{ka}$. Only 4 single OSL measurements of sample N3/3 show dates $>200 \mathrm{ka}$. The TL and OSL dates show inversions.
The Tyasmyn unit (ts) of thickness up to $1-2 \mathrm{~m}$ is a loess-like deposit ( $\mathrm{Md}=24.6-40.4 \mu \mathrm{m} ; \sigma=1.5-2.1)$. Its layers trace the shape of the former slope, and numerous Mn-Fe nodules (documented through micromorphology - Fig. 5E, F) tes- 
tify to periodic redox conditions in the post-sedimentation stage. What is specific for this loess layer is a distinct enrichment of the top and bottom in carbonates (6.7 and 8.2\%, respectively). Likewise, the content of organic matter is distinctly different, and clearly decreases with depth. There are also fossil burrows present, associated with the $p /$ soil unit.

Three dates of samples (N3/2, N3/1, and N2/8) from the ts loess are also characterized by inversion. The TL dates are a collection of dates from 110 to $130 \mathrm{ky}$ (Appendix 1), and OSL dates are a collection of dates from 116.4 to $129.5 \mathrm{ky}$ (Appendix 2). Dose rates for both methods are comparable with the lowest for sample N3/2. On the basis of the extreme dates above and below the set of soils $k d$, it can be inferred that this succession was formed over a period of several thousand years.

The Pryluky soil unit $(p l)$ is developed on the ts loess $(\mathrm{Mz}=$ 31.5-36.7 $\mu \mathrm{m} ; \sigma=1.5-1.8)$ which - on the higher parts of the fossil slope where the $k d$ soil is truncated - overlies directly the loess $d n$. The lower part of the unit $p$ is a chernozem $(1.4 \mathrm{~m}$ thick) composed of horizons A-Bk. In both of these horizons, strongly coloured pseudomorphs of krotovinas are filled with calcareous loess and humus material; krotovinas in horizon Bk occupy over half of that horizon's volume (Fig. 4B). Immediately above there are two superimposed interstadial soils. This indicates weak loess sedimentation and soil processes in the early glacial period. The soils are composed of horizons A-B and are 0.55 and $0.25 \mathrm{~m}$ thick respectively; the content of $\mathrm{CaCO}_{3}$ is relatively low (1.2-1.3\%). These are poorly developed and degraded chernozems rich in organic matter (3.1 and 3.9\%, respectively), with pedogenic Mn-Fe concretions (Fig. 5G, H), and numerous small worm tunnels. The whole unit is broken by deep cracks (Ukr. "kosma"), which start on the surface of the youngest soil and are filled with loess and carbonate concretions.

The dates of the soil of the younger part of the pl succession, based on samples N2/4 and N2/2, probably developed in a small time interval, as indicated by similar TL ages of $109 \pm 14$ and $112 \pm 16$ ky and almost identical equivalent dose values. The OSL values for this layer are also free of inversion and are $103.1 \pm 4.2 \mathrm{ky}$ and $109.2 \pm 4.2 \mathrm{ky}$ (Appendix 1$)$.

The carbonate loesses Uday $(u d)$ and Bug $(b g)$, which correspond to the Weichselian Glaciation, are not stratigraphically differentiated in the profile examined. They are spatially differentiated in thickness, from $>10$ to $\sim 0.5 \mathrm{~m}$. At the bottom they are clearly layered, but up the profile the layers are not so easily visible. These loesses are separated from aeolian sands in the upper part of the profile by a fossil Dofinovka soil $(d f), 1 \mathrm{~m}$ thick, of chernozem type, the surface of which is broken by a system of dissected narrow cracks completely coated with white hard carbonates (Fig. 4A).

The highest layer of loess, represented in its entirety in section 1, can be divided into two or three segments in the sense of the received age components. The first is the lowest with similar components: de and dr and an age from 142 to $135 \mathrm{ky}$ with slight inversion in the middle date. The OSL dates are younger than the TL dates, and show an inversion in the age range of 91.0 to $117.3 \mathrm{ka}$. Single OSL dates show a number of modalities from 2 to 3 and the widest range of single age measurements from all samples dated (Appendix 2). A characteristic feature of single measurements is that no individual sample in the entire set is younger than $78.9 \mathrm{ka}$. The next three samples were only TL dated and they have similar values for annual doses and distinctly different equivalent dose values, which resulted in significant differences in dates. The date of the highest sample N1/1 was $21.1 \pm 3.2 \mathrm{ka}$. This date correlates well with the AMS ${ }^{14} \mathrm{C}$ cal. date: 21360 cal. $21760 \mathrm{BP}$ (Poz-38013).

The Prychornomorsk unit $(p c)$ is a succession of aeolian silty sands and fine-grained sands $(0.9 \mathrm{~m}$ thick). The layer contains a zone strongly enriched in carbonates directly below the modern soil $h l$, and is fully cemented, which makes the sedimentary structures of the sands unclear. It contains an embryonic thin soil with a small thickness of up to $0.2 \mathrm{~m}$ and a simple A-B horizon layout.

The Holocene soil $(\mathrm{hl})$ has a thick $(1.3 \mathrm{~m}) \mathrm{A}$ horizon and a characteristic $B$ horizon $(0.7 \mathrm{~m})$ highlighted by a number of hardpan layers (Figs. 3 and $4 \mathrm{~A}$ ). It can be interpreted as a pedocomplex composed of a grey forest soil and superimposed degraded chernozem.

Significance of luminescence dates. Twenty TL dates, 14 OSL dates and one radiocarbon date were unable to solve problems of interpretation of the loess in the Nahirne region. The set of TL dates for the samples taken from the three profiles formed a sequence of $220 \pm 33 \mathrm{ky}$ in the floor to $21.1 \pm 3$.2 ky at the top with numerous inversions. The OSL date set does not include the youngest dates (N1/4, N1/5 and N1/6) and is a set with age inversions within and beyond $100 \mathrm{ka}$. A characteristic feature of the entire set of luminescent dates is that the TL dates are always older than the OSL dates, and the date comparison of the same samples indicates simultaneous inversion in both sets. All TL dates except three are dates over one hundred thousand years. The reliability of the TL dates is supported by the OSL dates, especially the sets of single date ranges and multimodality. The wide age range of single OSL measurements indicates, on the one hand, that in the samples examined there were grains of different ages, but at the same time there were grains whose age was not younger than $78.9 \mathrm{ka}$. TL dating conducted in the Gdańsk laboratory with the method of multiple portions averaged the age of all grains measured. It can therefore be assumed that almost all luminescent dates from the loess $u d$ and below this layer have been rejuvenated. Even the dates of the homogeneous $b g$ loess are almost the same age in the profile section of 9 to $12 \mathrm{~m}$ and range from 135 to $142 \mathrm{ka}$. The OSL dates in the same section are from 91.0 to $117.3 \mathrm{ka}$. This time, these sets form a collection of dates that are younger than expected. This patter is also seen in the set of dates of single OSL measurements. They are undoubtedly aged and this can be the result of a quick and short transport. This can be seen from the high sedimentation rate at the lower part. The rest of the dates are undoubtedly younger than expected. Six samples of the ts and $d n$ loess, although also rejuvenated, allow some interpretations. This was difficult to do for the samples taken from fossil soils. But in this case, we can talk about dates distorted due to the effects of small pedofauna, changing the material that builds the soil. For this reason, the Nahirne site was a difficult research site for dating. At $20 \mathrm{~m}$ of the profile section half of its thickness was soil, and this material is difficult to date. This requires much caution in making attempts to date such sites. Not all scholars will even accept such work (Frechen et al., 1997, 1999, 2003; Li et al., 2011; Schmidt et al., 2011; Fuchs et al., 2013). In cases such as the one discussed in this paper, it is worth doing because dating helps solve, if not the age details of the individual layers, more the problem of the age of the loess in the entire profile, which is a palaeogeographical problem.

\section{VELYKA ANDRUSIVKA SITE}

Litho-pedostratigraphic units. The Velyka Andrusivka profile (Fig. 1B) shows the structure of the cover on the 4th terrace of the Dnieper. The cover is bipartite (Putevoditel..., 1999; Komar et al., 2004, 2005). The lower part (9 m) is composed of a succession of fluvioglacial deposits including basal moraine $(5 \mathrm{~m})$ and the upper part with the loess-soil sequence that includes the Dnieper loess ( $d n$ ) to a modern Holocene soil ( $h l$ ), including several fossil soils of different ranges (Fig. 6; Putevoditel..., 1999). 
Quartz prevails in the light fraction (86-98\%) of the loesssoil succession. In some parts it shows traces of aeolian action and in some of a subaqueous environment. Of considerable content is glauconite (up to $11 \%$ ), which is moderately abundant in the underlying Paleogene rocks. Content of feldspars is $2 \%$. Ilmenite is the most representative element of the heavy fraction (up to $48 \%$ ). Garnet content reaches $21 \%$. Zircon is present in all samples (29\%). Hornblende reaches $11 \%$. Rutile is moderately abundant (up to $17 \%$ ). Disthene content is up to $9 \%$ and tourmaline is $6 \%$, while that of epidote and biotite is 5 and $4 \%$, respectively. Carbonate (the main body of calcite) content ranges from 5 to $10 \%$. Carbonates are more abundant in loess than palaeosol.

Pollen analysis. L PAZ VA-1: the sample of $22.6 \mathrm{~m}$ depth has the lowest number of tree and shrubs pollen (Picea, Pinus, Alnus). A low amount was also noted of pollen of cold-loving taxa such as Alnaster fruticosus (=Alnus fruticosa), Betula nana, and Salix polaris. The NAP value is $67 \%$ and their composition is relatively homogeneous. Pollen of Artemisia, Chenopodiaceae, Cichoriaceae, and Brassicaceae dominates. There are lesser amounts pollen of Thalictrum and Saxifragaceae. A characteristic feature is the presence of spores of Selaginella selaginoides, Sphagnum and Riccia, and individual specimens of Pediastrum kawraiskyi Schmidle and P. simplex Meyen. The number of redeposited palynomorphs reaches up to $30 \%$ of the total basic sum. Reconstructed MTC is -10 to $-25^{\circ} \mathrm{C}$; MTW cannot to be estimated.

L PAZ VA-2: the nature of the two samples varies slightly. The percentage of AP increases. Simultaneously, cold-tolerant pollen almost disappears. Composition of NAP and P records shows increasing diversity. Reconstructed temperatures are: MTC -10 to $-19.5^{\circ} \mathrm{C}$, MTW 13 to $+17^{\circ} \mathrm{C}$.

L PAZ VA-3: towards the top (depth 18.5-16.0 m), the content of tree and shrub pollen further increases. Pollen of deciduous trees appeared, such as oak (Quercus) and elm (UImus) and, at the end of the interval, hornbeam (Carpinus). In addition, the percentage of pollen of shrubs of Crataegus, Rham nus, Viburnum increased. The composition of NAP becomes more diverse. A small amount of local pollen like Potamogeton and Sparganium was found. The percentages of fern spores (Polypodiaceae) and Bryales mosses increase. In addition to pollen and spores, the algae Pediastrum duplex, $P$. simplex, $P$. boryanum and Botryococcus are present individually in the spectra. MTC -4 to $+1^{\circ} \mathrm{C}, \mathrm{MTW}+15.5$ to $+21^{\circ} \mathrm{C}$.

L PAZ VA-4: in the pollen spectra at depth 15.8-15.4 m, composition as well as AP percentage change from 55 to $38 \%$. Pine pollen dominates. Among NAP Artemisia and Chenopodiaceae pollen dominate. The herbaceous variety is reduced and pollen of cold climate plants such Linnea borealis, Thalictrum alpinum appears. Bryales and the redeposited sporomorphs noticeably increase. MTC -6 to $+8^{\circ} \mathrm{C}, \mathrm{MTW}+12$ to $+21^{\circ} \mathrm{C}$.

L PAZ VA-5: the feature of the 14.9-13.9 m interval samples is the gradual change in the dominant AP components with an increase of shrubs (to $30 \%$ ) and the maximum number of hazel Corylus pollen (25\%). The number of spores of Polypodiaceae and Bryales moss increase again. MTC -4 to $+1^{\circ} \mathrm{C}$, MTW +15.5 to $+21^{\circ} \mathrm{C}$.

L PAZ VA-6: the pollen spectra at the depth 13.5-12.5 m are dominated by Pinus pollen with a small admixture of Picea, Quercus, and Carpinus. The herbaceous pollen belongs to the families Poaceae, Asteraceae (including Artemisia species), Chenopodiaceae, Cichoriaceae, Cistaceae, Euphorbiaceae, Plumbaginaceae, Ranunculaceae, Saxifragaceae, and Scrophulariaceae. The proportion of pollen of open habitat plants increases. MTC -15 to $+1^{\circ} \mathrm{C}, \mathrm{MTW}+13$ to $+21^{\circ} \mathrm{C}$.
Small mammals and molluscs. Layered gravels at depths of 25.6-26.1 m contained isolated remains of small mammals (Ochotna sp., Ellobius sp., Mimomys sp., Microtus cf. Oeconomus). Shell molluscs were also found here. Fauna of land molluscs is represented by Succinea oblonga, S. oblonga elongata, S. sf. Putris, and Vallonia tenuilabris. Fauna of water molluscs is more numerous and rich, and is represented by Euglisa? sp., Valvata pulchella, V. sf. Trochoidea, V. klinesis, Bithynia sp., Lymnea (Stagnicola) palustris, L. (Corvusiana) corvus, L. sp. ind., Planorbis planorbis, Anisus (Anisus) spirorbis (Komar et al., 2005).

\section{LANDSCAPE CHANGES OF THE DNIEPER UPLAND FROM MIS 8 TO MIS 2}

The characteristics of the changes were based on the data from the two sites analysed. Additionally, information from the Maksymivka profile (Fig. 8), in which palynological studies (Gozhik et al., 2014) were also performed, was considered. Mineralogical studies at Velyka Andrusivka show that the main sources of loess sediment in the Dnieper loess area were underlying Paleogene rocks, fluvioglacial deposits and to some extent weathered younger deposits (Komar et al., 2004, 2005), indicating local deflation areas and rather short transport (vide Chlebowski et al., 2003). The small variation in the composition of heavy minerals throughout the profile suggests a stability of these source areas throughout the entire sedimentation period. Reconstructed palaeowind directions in mid-part of Ukraine during the Weichselian was W and WNW to N (Ró ycki, 1986; Buggle et al., 2008; Bokhorst et al., 2011).

The palynological studies of the above-mentioned loess profiles area indicate, that the Pleistocene landscape in the Middle Dnieper showed on the one hand the constant presence of small groups of trees in the cold steppe during periods of climatic deterioration, and on the other hand, a lack of full afforestation even during interglacial climatic optima (Komar, 2010). These warm periods were characterized by a mosaic of forest, steppe and meadow under which developed forest-steppe soils consisting of boreal brown soils, chernozems (still with features of meadow chernozems and leached chernozems), brown, grey and light grey forest soils and hydromorphous soils (Matviishina, 1982; Gozhik et al., 2001a; Gerasimenko and Rousseau, 2008).

For the central part of the Dnieper River Valley the period of the Dnieper I Glaciation was a time of fundamental change in the natural environment. The earlier relief, of mainly denudation-fluvial type, underwent significant glacial modification. The ice sheet recession left fresh marginal glacial forms. A drainage network formed using glacial outflow channels (Chugunny and Matoshko, 1995; Matoshko, 1999, 2011b). The vegetation was rebuilt, and the relict species were fully and definitively eliminated (Gozhik et al., 2014). Micropalaeontological (Komar et al., 2005) and palynological studies of fluvioglacial deposits and Dnieper loess ( $d n)$ at the Velyka Andrusivka site show that a mosaic of steppe and park tundra appeared with meadow and shrub-meadow vegetation in the valleys of the Dnieper Upland. A fauna of land molluscs indicated a mosaic of relatively wet and dry grass habitats (Figs. 6 and 7). Stagnant or slow-flowing periglacial waters fed shallow lakes, marshes, ditches and pools which served as natural habitats for aquatic molluscs. Small mammals inhabited well-developed systems of ravines and gullies by lakesides, marshes and former riverbeds with rich vegetation. Families of Chenopodiaceae, Cichoriaceae, Brassicacea, Asteraceae (Artemisia) as well as mosses with 
slight participation of Betula sect. Nanae et Fruticosae played a major role in the plant cover. In depressions edaphic and climatic conditions allowed the encroachment of plants adapted to permafrost, such as Picea excelsa, Betula nana, Selaginella salaginoides, Botrychium multifidum. Also there was a mosaic of steppe and some tundra with small patches of cold-resistant trees and shrubs (Betula sect. Nanae et Fruticosae, B. sect. Alba, Pinus sylvestris, Picea abies, Hippophaë rhamnoides, Salix and Alnus) in the of the Dnieper Lowland (Maksymivka site).

A relatively cold continental climate after the ice sheet retreat favoured aeolian processes. The intensity of the loess accumulation was spatially varied from only $0.7 \mathrm{~m}$ at Maksymivka to $>3 \mathrm{~m}$ at Velyka Andrusivka (Fig. 8). In the area of the Nahirne site there is evidence that the $d n$ loess partially filled up a palaeodepression, $\sim 40 \mathrm{~m}$ in width in its eastern part (the remaining parameters cannot be reconstructed). In other places loess creates a (sub-)horizontal layer. The age of the loess $d n$ is constrained by the dates of the Nahirne profile: 220 and $139 \mathrm{ky}$. The second date is evidently rejuvenated (139 ky), probably as a consequence of intense later processing of $d n$ loess by deep-penetrating small pedofauna, which resulted in the loess being mixed with much younger material.

At the end of MIS 8, the thawing permafrost of the Dnieper Upland allowed the encroachment of a richer vegetation with trees such as Quercus and UImus and finally Carpinus, an increasing proportion of shrubs (Crataegus, Rhamnus, Viburnum), as well as ferns (Polypodiaceae) and mosses (Bryales). The local components of the plant communities were Potamogeton and Sparganium (Fig. 6). On the Dnieper Lowland among the trees were mainly pine and birch, with a individual willow, sea buckthorn, spruce and alder. Linnea borealis points to the existence of tundra and boreal coniferous forest communities.

MIS 7 (243-191 Ka)

The interglacial following the Dnieper I Glaciation was a time of varied climate. On the isotope oxygen curve depicting MIS 7, three warmer substadia can be delimited (Thompson and Goldstein, 2006; Cohen and Gibbard, 2011). These fluctuations are recorded in the complex nature of the soil processes recorded and the evolution of the plant cover. In the loess profiles of Ukraine, this period is usually represented by two well-developed soils that either overlap or are separated by a solifluction horizon (seasonal?) and/or loess. In the western part of Ukraine, a unit called Korshiv is represented by two forest soils, sometime truncated, and in Podolia more complex pedocomplexes, where chernozem can be deposited on the forest soil. In central and especially southern Ukraine, a unit called Kaydaky $(k d)$ has the basic form of a double, less commonly a single, chernozem in different variants (Łanczont et al., 2014), also in the succession with grey forest soils, as observed in large exposures of the Kyiv Plateau (Putevoditel..., 1999). In these areas, the $k d$ unit often creates one unit with the $p /$ unit, with or without the slightest involvement of the ts loess between them, with certain consequences in their stratigraphic interpretation. Because of this fact, some researchers are of the opinion that these two units should be treated as one and correlated only with MIS 5 (Gerasimenko, 2006; Buggle et al., 2009). This issue has recently been widely discussed by Łanczont et al. (2014) by considering arguments from the area between the Vistula and the Dnieper concluding that the above interpretation is debatable. A temporal separation of $k d$ and $p /$ horizons is also supported by the results of studies of numerous loess pro- files of the Volhynia-Podolia Upland and the Black Sea region (e.g., Bogucki et al., 1980; Gozik et al., 1995; Shelkoplyas, 2001; Shelkoplyas and Khristophorova, 2005; Lindner et al., 2006; Bogucki and Łanczont, 2011). In particular, evidence came from archaeological data from the Podolia region, where well-defined, culturally diverse mid-Palaeolithic artefacts are present in superposition within the Kaydaky soil, Tyasmyn loess and Pryluky soil (Łanczont et al., 2013b).

In the Middle Dnieper area, the young-glacial relief showing diverse forms and elevation ranges, was of the greatest importance for the developing vegetation and soil cover. Postglacial relief was additionally modified and partly masked by loess accumulation. With the recession of the permafrost in the early part of the interglacial, drainage conditions changed and the level of groundwater decreased. Although for woody plants with a deeper root system these conditions were more favourable, the encroachment of forest vegetation into new ground was very slow. This would indicate that thermal conditions were still not very favourable and were possibly at a significant distance from the refugial areas. During the glacial periods the Dnieper Valley served as a refuge in which the various species of trees survived and from where they later spread (Komar, 2010); however, the distance to the SE of the glaciated area $(100 \mathrm{~km}$ from the Nahirne site) could have been a real obstacle to the survival of less resistant trees in its immediate vicinity. The initial stage of the spread of woodland is signalled by pine forests with birch and alder, and with ferns in the undergrowth on sandy river terraces. Later improvement in both winter and summer thermal conditions allowed for greater variability in the structure and organisation of biogeocenoses, and thermophilous deciduous trees encroached into these forests: in the Dnieper Upland these were Quercus robur, Q. petraea, Ulmus laevis, Carpinus betulus, while in the Dnieper Upland these additionally included Tilia, Acer, Carpinus, Alnus, Frangula alnus and Sambucus (Komar et al., 2009). Conditions were good for the development of shrubs with the main components being hawthorn, viburnum and hazel. During the entire MIS 7 in the vegetation cover of the discussed area of the Middle Dnieper, communities of herbaceous plants with a high proportion of mesophilic elements played an important role.

In the pollen record of the Velyka Andrusivka profile (Fig. 7), the interglacial cooling period is poorly represented. It may be represented by the layer at a depth of 16.6-16.3 m; at its bottom there are only traces of pollen, while above, a decrease in the areas occupied by trees is represented. In the Velyka Andrusivka the MTC temperature fluctuation range was from -4 to $+1^{\circ} \mathrm{C}$ and of MTW from +15.5 to $+21^{\circ} \mathrm{C}$ (Fig. 6). On the other hand, winter periods at the Maksymivka site (Gozhik et al., 2014) were slightly cooler (MTC in the range of -4.5 to $+4^{\circ} \mathrm{C}$ ) and the summer periods warmer (MTW $17-21^{\circ} \mathrm{C}$ ).

The soil cover of MIS 7 in the valleys of the Dnieper Upland was formed on a diverse postglacial surface covered by an uneven layer of the loess $d n$. The Nahirne site is a good example of the evolution of the soil cover within the depression bottom. Three overlapping soils of a type of hydromorphic meadow chernozem in the 2010 profile indicate constant hydromorphic conditions. It seems that this part of the palaeodepression was dominated by steppe-meadow vegetation throughout the entire period of soil cover formation. The loess layer between the lower and middle soil is an indicator of the coolness and dryness of the climate preceded by a more humid phase which facilitated erosion processes eliminating the oldest soil horizon. Observations made in 1999 on another, and probably higher, section of the analysed palaeodepression, allow us to infer that forest vegetation could have periodically encroached onto this place, and the grey forest soils which developed below and 
which were not resistant to slope processes, were more easily denuded when the conditions became less favourable for trees. Undoubtedly, the study area was covered by a mosaic of steppe-forest vegetation of varied ranges during the Kaydaky warming.

The TL and OSL dates for the $k d$ unit in the Nahirne profile do not permit the conclusion that individual horizons are of various ages (Fig. 6). The reason includes numerous inversions; in the upper (younger) layer, all dates are older than the date in the bottom part. The factor which led to the rejuvenation of the samples in the soil succession described is undoubtedly the unusually high activity of pedofauna, living in the Kaydaky period and also in the younger Pryluky period, and the subsequent contamination of the soil material.

$$
\text { MIS } 6(191-130 \mathrm{Ka})
$$

The cold and dry climate of MIS 6 was marked by the activation of slope and aeolian processes. This activity is documented by the colluvial, laminated type of the loess ts (with $d$ inserts of coarse sand) and its small thickness (Velyka Andrusivka $0.6 \mathrm{~m}$ and Nahirne $-0.8-1.6 \mathrm{~m}$ ). This is why it has often been transformed entirely by soil-forming processes and acts as a substrate for the subsequent interglacial soil, i.e. Pryluky, as for example at the Maksymivka site (Gozhik et al., 2014). The TL age of the ts loess in Nahirne (Fig. 4) was 110-130 ky and OSL age was 117-129 ky, i.e. this one is clearly younger (and even rejuvenated).

Undoubtedly, at the beginning of the penultimate glaciation, slope processes were very intense and spatially differentiated, resulting in the first stage of remodelling of the fossil valley forms. In the Velyka Andrusivka area, colluvial sediments originating from the erosion of the $k d$ soil were deposited along the axis of the depression. The slopes of this form were remodelled with local elevation ranges diminished due to significant or complete denudation of the Kaydaky soil cover (Putevoditel..., 1999), and locally fragmented by secondary erosive forms.

The sedimentation of $t s$ loess occurred in a cold periglacial steppe, mainly composed of Asteraceae, Chenopodiaceae, Cichoriaceae, Plumbaginaceae, with cold climate indicators (Linnea borealis L., Thalictrum alpinum L.). In more humid areas there was steppe-meadow vegetation. Trees and shrubs formed small patches in terrain hollows and in secluded places, disappearing completely in higher areas, resulting in the above-mentioned intensified soil erosion and the development of pioneer plants. The reconstructed temperature range for this section of the Velyka Andrusivka profile (Fig. 6) is MTC $-16 \ldots+8^{\circ} \mathrm{C}$ and $\mathrm{MTW}+12$ to $+21^{\circ} \mathrm{C}$. In the Maksymivka profile, the temperature range has not been reconstructed.

$$
\text { MIS } 5(130-71 \mathrm{Ka})
$$

The period of the Eemian interglacial and the early phase of the interglacial-glacial climate fluctuations corresponding to MIS 5, in the area analysed of the Middle Dnieper, is represented very differently in the course of soil-forming processes and the degree of preservation of fossil soils. In this respect, this period is most completely expressed in the Maksymivka site by a sequence of superimposed interglacial chernozem and three bipartite interstadial soils (the lower one developed as a grey forest soil, the two upper ones as poorly developed leached chernozem), TL dated at 130-76 ky (Gozhik et al., 2014). However, in the right, western side of this area, the profiles of the $p /$ unit may be incomplete and/or blurred, as at Velyka Andrusivka (Fig. 6), where the $p /$ unit is visible as a for- est soil with traces of erosion in its top part. At Nahirne, the unit $\mathrm{pl}$ is better developed; it is composed of an interglacial chernozem with the genetic profile of $\mathrm{A}-\mathrm{Bk}$ and two interstadial chernozems with TL ages of 112 and 109 ky and OSL ages $\sim 109$ and 103 ky (respectively). Therefore two interstadial chernozems probably developed in the older part of the Early Glacial.

The beginnings of the formation of the $p /$ soil unit on the Dnieper Upland took place during the period of gradual growth of deciduous trees, including linden and hornbeam, which was more pronounced than on the Dnieper Lowland, and hazel. The main difference between the vegetation cover of the right and left bank of the Dnieper River Valley is the more varied composition of the undergrowth and the presence of walnut (Juglans) among trees on the left bank (Maksymivka site). Little difference is seen in temperature. For Velyka Andrusivka (Fig. 6) it is reconstructed at MTC -4 to $+1^{\circ} \mathrm{C}, \mathrm{MTW}+15.5$ to $+21^{\circ} \mathrm{C}$, for Maksymivka $-\mathrm{TC}-4.5$ to $+1^{\circ} \mathrm{C}, \mathrm{MTW}+17.5$ to $+21^{\circ} \mathrm{C}$ at the beginning of the interglacial, and MTC -4.5 to $+3.5^{\circ} \mathrm{C}, \mathrm{MTW}+17.5$ to $+21.5^{\circ} \mathrm{C}$ in the post-optimum phase.

The interstadial conditions of the early glacial were characterized by depletion of forest composition (Fig. 7), dominated by pine with birch, spruce, oak and hornbeam, and widespread forest-steppe with rich grass vegetation (with representatives of the Poaceae, Asteraceae, Chenopodiaceae, Cichoriaceae, Cistaceae, Euphorbiaceae, Plumbaginaceae, Ranunculaceae, Saxifeagaceae and Scrophulariaceae).

$$
\text { MIS 4-2 (71-12.5 Ka) }
$$

Environmental changes related to the lower Pleni-Weichselian climate were drastic, as seen from very deep periglacial fissures breaking up the surface of the $p /$ soil unit, and filled with aeolian loess. This significant cooling of the beginning of the Pleniglacial is signalled by a significant decrease in the MTC temperature to a range of -16 to $+1^{\circ} \mathrm{C}$ at the Maksymivka site (Komar et al., 2009), and -15 to $+1^{\circ} \mathrm{C}$ at the Velyka Andrusivka site. There are numerous secondary carbonates in the fissures, which reflects the subsequent change in climatic conditions allowing the activation of carbonate movement and precipitation in predisposed places.

The Pleniglacial loess accumulation cycle was another stage in remodelling the relief across the Middle Dnieper area. The older palaeodepressions were infilled with loess (Fig. 2A). Pleniglacial loess in the Nahirne profile with a thickness of up to $7.5 \mathrm{~m}$ is non-carbonate; it is massive, lithologically undifferentiated, with no trace of stratification besides in its bottom part, and no Vytachiv marker horizon is detected, and therefore no stratigraphic separation of the Weichselian loess is possible. This is a strictly local situation (see Kolstrup, 1994), because the $v t$ pedounit as a grey forest soil with a thickness of 1.5 is represented at the neighbouring Velyka Andrusivka between the $u d$ loess $(2.8 \mathrm{~m})$ and $b g$ loess $(8.6 \mathrm{~m})$. The age of the loess $u d / b g$ in Nahirne, much older than expected, can be indirect evidence to help to reconstruct its transport and accumulation conditions. On one hand, this may indicate that this Weichselian loess included material sourced from blowing older loess, soil and glacial deposits, which can be attributed to the local damage of the vt soil (truncation) and, on the other, of local short transport, so that the zeroing conditions of quartz grains by sunlight were not met. The ud loess in the Maksymivka profile is very thin, largely transformed by pedogenesis $v t$, but the loess bg is almost $5 \mathrm{~m}$ thick and has a sandy bottom layer, which is considered as reflecting an episode of strong deflation (Gozhik et al., 2014). 
The $u d$ period was marked by cold and dry climate in the Middle Dnieper area, as indicated by the development of cold steppe communities with Poaceae, Asteraceae (Artemisia), Cistaceae (Helianthemum). The thinning of the plant cover was a circumstance conducive to aeolian erosion. At that time, small groups of trees with little variability in species composition had the chance to survive in the most secluded depressions. The younger layers of pleniglacial deposits, $v t$ and $b g$, did not undergo palynological examination at the Velyka Andrusivka site.

The Bug loess $(\mathrm{bg})$ bed is highly varied in thickness from 2 to even $18 \mathrm{~m}$ not only on the regional scale (Gozhik et al., 2001a; Gerasimenko, 2006), but also on the local scale, mainly in relation to the local palaeorelief, as seen in long exposures in the cliff between Velyka Andrusivka and Nahirne. The homogeneous nature of the $b g$ loess is a reflection of the generally dry and cold climate during deposition, but with oscillations of milder conditions during the post-Last Glacial Maximum. In the Bug loess $(b g)$ profiles, these are recorded as 1-3 horizons indicating intensification of soil-forming processes. The Dofinivka $(d f)$ unit is preserved in the Middle Dnieper area, relatively rarely, in slope loess and in palaeodepressions as a gley soil or rendzina type rich in $\mathrm{CaCO}_{3}$ (Gozhik et al., 2001a; Gerasimenko, 2006; Gerasimenko and Rousseau, 2008). Its counterpart in the western part of Ukraine is the Rivne stratigraphic unit, whose age was determined by luminescence methods at 20-23 ky (Fedorowicz et al., 2013). This age correlates with the phase of transitory climatic improvement recorded in Western and Central Europe sequences, as indicated by Guiter et al. (2003), at 22-23 ky. In the sections near the Black Sea area the Dofinivka unit ${ }^{14} \mathrm{C}$ age is estimated between 19 and $15 \mathrm{ky}$ BP (Gozhik et al., 2001a).

The soil correlated with the $d f$ unit in the Nahirne profile ends its loess section. It is basically a $B$ horizon pedocomplex, similar to a grey forest soil and a superimposed chernozem, which would indicate a two-stage development. It is the soil in which the processes of redistribution of carbonates are strong. Its typological features are close to those of the $d f$ unit described by Gerasimenko (2006). In the Nahirne profile, the date of the $\mathrm{N} 1 / 6$ sample from the A horizon of the $d f$ soil, radiocarbon (21.36-21.76 ky BP) and TL (21.1 $\pm 3.2 \mathrm{ky})$, correlate well, although the TL should generally be older than the radiocarbon date. The ${ }^{14} \mathrm{C}$ date uncertainty interval is within the uncertainty interval of the TL date. So, if both dates are so compatible, then one might think that the soil formation was relatively short and the prevailing climatic conditions were conducive to the accumulation of humus.

Deep narrow cracks in the top of the $d f$ soil cover, filled with carbonate material, testify to the cold and dry climatic conditions that followed the formation of this soil. The timing of these phenomena is difficult to determine. One indicative fact might be that the soil developed on the loess is overlain by sandy-dust material, which would suggest a connection with the Late Glacial sedimentation time. The sands above the loess may represent the phase of the development of sandy covers and dunes that form isolated thin local near-surface sand blankets (Matoshko, 2011b). In profiles on the Black Sea, the Prychornomorsk loess $(p c)$ was developing at that time. With such an interpretation, it would be justified to link the initial soil separating these sands with the warming of the Late Weichselian, i.e. with the Bølling and Allerød (Gozhik et al., 2007). Probably it was also yet another stage of transforming the relief of the small valleys on the right slopes of the Dnieper Valley, the last such event in the Pleistocene. In the Nahirne vicinity it is seen as the youngest small and deep valley developed at the contact with the Paleogene sands and inserted into the loess cover, which is rhythmically completely infilled with fine-grained sand (Fig. 2D).

\section{CONCLUSIONS}

1. The exposure of the cliff of the Nahirne area gave the possibility of reconstructing several consecutive morphogenetic phases of the original postglacial relief. Palaeodepressions in the postglacial relief were remodeled several times by erosion, colluvial processes and loess sedimentation in subsequent cold cycles, after the stage of pedogenesis and surface stabilisation. The layers filling fossil forms are inclined to various degrees, some "go out into the air". The youngest subsurface loess bed of varying thickness covers these elements of the palaeorelief, and the youngest generation of valleys was developed in the Late Glacial period.

2. An important feature of fossil catenas is their morphological variability reflecting the character of relief formed during particular pedogenic and/or post-pedogenic stages. Finally, truncated and eroded soils are also good markers of younger evolution stages of the environment recorded in the discontinuity of pedounits and the declining of fossil horizons at elevated locations.

3. Loesses in the Middle Dnieper Area were formed in conditions of short transport of the dust material mainly from local fresh glacial deposits and the underlying Paleogene rocks. The source areas were stable throughout the entire sedimentation period.

4. The obtained TL and OSL dates show that we are dealing in the Nahirne profile with loesses that were undoubtedly developed after the maximum glaciation period in the area, and not before it. Individual results support this, and the others are by no means older than MIS 7. As a result, the issue of the Nahirne loess age should no longer be questionable. For the Nahirne profile, no valid luminescent date corresponding to MIS 7 was obtained, unlike for the profiles of Velykyi Glyboczok, Maksymivka and Stari Kodaky in western Ukraine (Łanczont et al., 2014).

5 . The absence of traces of solifluction in the profiles analysed indicates that the wetter glacial climate was manifested via colluvial processes. This would indicate that permafrost has not been present in the area examined since the end of MIS 8.

6. Conducted field studies supplemented with the results of laboratory analyses allowed correlation od the oldest fossil soils in the Nahirne profile with MIS 7. The stratigraphic units Kaydaky $(k d)$ and Pryluky $(p l)$ are separated by the Tyasmyn (ts) loess correlated with MIS 6 (Fig. 8). This soil sequence cannot be interpreted as the equivalent of one MIS 5 interval, with the association of the ts loess with substadial $5 \mathrm{~d}$, as was suggested by Gerasimenko (2006). The individual characteristics of the palynology of the Kaydaky period (Velyka Andrusivka, Maksymivka) do not allow assignment to the Kaydaky soil unit $(k d)$ as regards the stratigraphic position of the lower part of the Pryluky unit (=the Eemian Interglacial), and the individual features of the palynology of the entire Pryluky period indicate that they cannot be interstadials of the Early Weichselian.

Acknowledgements. The study was carried out as part of the project No. NN306 474138 supported by the Ministry of Science and Higher Education. Granulometric analyses were performed on the basis of the analyser purchased under the Operational Program Development of Eastern Poland 2007-2013. Priority Axis I: Modern Economy. Activity I.3. Support for innovation. "The growth of the R\&D potential of the Departments of Chemistry and Biology and Earth Sciences, Maria Curie-Skłodowska University in Lublin". The authors thank Professor A. Makeev and an anonymous reviewer for their insightful comments and suggestions. We especially wish to also extend our deep gratitude to the Editors for their outstanding and detailed comments and suggestions on our manuscript. 


\section{REFERENCES}

Bogutsky, A.B., Velichko, A.A., Gerenchuk, K.J., Gruzman, G.G., Demediuk, N.S., Zalesskiy, I.I., Kravchuk, J.A.S., Morozova, T.D., Nechyev, V.P., Palienko, V.P., Tsatskin, A.l., Chugunny, J.G., 1980. Opornye razrezy y krayevye obrazovanyamaterikovykh oledenenyi zapadnoy chasti Ukrainy (in Russian). Inst. Geol. Nauk Akad. Nauk USSR. Preprint, Kiev, 80-17: 1-50.

Bogucki, A.B., Łanczont, M., 2011. The Korshiv profile compared to stratigraphic subdivisions of loesses in Europe. In: International Workshop - 6th Loess Seminar in Wrocław (Poland) North Carpathian loess traverse in the Eurasian loess belt, abstract and field guide book: 71-72.

Bokhorst, M.P., Vandenberghe, J., Sümegi, P., Łanczont, M., Gerasimenko, N.P., Matviishina, Z.N., Marković, S.B., Frechen, M., 2011. Atmospheric circulation patterns in Centra and Eastern Europe during the Weichselian Pleniglacial in ferred from loess grain-size records. Quaternary International, 234: $62-74$

Buggle, B., Glaser, B., Zöller, L., Hambach, U., Markovicě, S., Glaser, I., Gerasimenko, N., 2008. Geochemical characterization and origin of Southeastern and Eastern European loesses (Serbia, Romania, Ukraine). Quaternary Science Reviews, 27 1058-1075.

Buggle, B., Hambach, U., Glaser, G., Gerasimenko, G., Marković, S., Glaser, I., Zöller, L., 2009. Stratigraphy, and spatial and temporal paleoclimatic trends in Southeastern/Eastern European loess-paleosol sequences. Quaternary International, 196: 86-106.

Chlebowski, R., Gozhik, P., Lindner, L., Łanczont, M., Wojtanowicz, J., 2003. Stratigraphy and sedimentology of the Bug loess (Pleistocene: Upper Vistulian) between Kiev and Odessa (Ukraine). Geological Quarterly, 47 (3): 261-268.

Chugunny, Y.G., Matoshko, A.V., 1995. Dnieper glaciation till de posits of ice marginal zones. In: Glacial Deposits in North-East Europe (eds. J. Ehlers, S. Kozarski and P.L. Gibbard): 294-256. A.A. Balkema, Rotterdam, Brookfield.

Cohen, K.M., Gibbard, P., 2011. Global Chronostratigraphical Correlation Table for the Last 2.7 Million Years. Subcommission on Quaternary Stratigraphy (International Commission on Stratigraphy), Cambridge, England.

Fedorowicz, S., Łanczont, M., Bogucki, A., Kusiak, J., Mroczek, P., Adamiec, G., Bluszcz, A., Moska, P., Tracz, M., 2013. Loess-paleosol sequence at Korshiv (Ukraine) - chronology based on complementary and parallel dating (TL, OSL), and litho-pedosedimentary analyses. Quaternary International, 296 117-130.

Frechen, M., Horvath, E., Gabris, G., 1997. Geochronology of Middle and Upper Pleistocene Loess Section in Hungary. Quaternary Research, 48: 291-312.

Frechen, M., Zander, A., Cilek, V., Lozek, V., 1999. Loess chronology of the last interglacial/glacial cycle in Bohemia and Moravia/Czech Republic. Quaternary Science Reviews, 18: 1467-1493.

Frechen, M., Ochesb, E.A., Kohfeldc, K.E., 2003. Loess in Europe - mass accumulation rates during the Last Glacial Period. Quaternary Science Reviews, 22: 1835-1857.

Fuchs, M., Kreutzner, S., Rousseau, D.-D., Antoine, P., Hatte, Ch., Lagroix, F., Moine, O., Gauthier, C., Svoboda, I., Lisa, L., 2013. The loess sequence of Dolni Vestonice, Czech Republic: A new OSL - based chronology of the Last Climatic Cycle. Boreas, 42: 664-677.

Gerasimenko, N., 2006. Upper Pleistocene loess - palaeosol and vegetation successions in the Middle Dnieper Area. Ukraine. Quaternary International, 149: 55-66.

Gerasimenko, N., Rousseau, D.-D., 2008. Stratigraphy and paleoenvironments of last Pleniglacial in the Kyiv Loess Region (Ukraine). Quaternaire, 19: 293-307.

Goretsky, G.I., 1970. Alluvialnaya "letopis" velikogo pra-Dniepra (in Russian). Nauka, Moskva.

Gozhik (Hozhyk), P.F. ed., 2000. The Map of Quaternary Formation of Ukraine, scale 1:1000 000. State Geological Service of Ukraine.
Gozhik (Gozik), P.F., 2008. Pleistocene glaciations in Middle Dnieper Valley (Ukraine). In: XV Konferencja Stratygrafia plejstocenu Polski, Plejstocen Tatr i Podhala - zlodowacenia tatrzańskie (in Polish). Państwowy Instytut Geologiczny, Warszawa: 35-35.

Gozhik (Gozik), P.F., Chugunny, Y.G., 1981. On the Middle Pleistocene glaciation of Ukraine (in Russian). In: Pleistocene glaciations at the East European Plain (eds. A.A. Velichko and M.A. Faustova): 86-91. Nauka, Moscow.

Gozhik, P.F., Gerasimenko, N.P., 2011. The Lower and Middle Pleistocene of Ukraine. In: Quaternary studies in Ukraine to the XVIII Congress of the International Union for Quaternary Research, Bern (eds. N.P. Gerasimenko, P.F. Gozhik, N.I. Dykan, V.M. Matviishina, V.M. Shelkoplayas and B.D. Vozgrin): 9-26.

Gozhik (Go ik), P., Shelkoplyas, V., Khristoforova, T., 1995. Development stages of loessial and glacial formations in Ukraine (Stratigraphy of loesses in Ukraine). Annales UMCS, sec. B., 50: $65-74$.

Gozhik, P., Matviishina, Zh., Shelkoplyas, V., Palienko, V., Rakovets, L., Gerasimenko, N., Korniets, N., 2001a. The Upper and Middle Pleistocene of Ukraine. In: The Ukraine Quaternary explored: the Middle and Upper Pleistocene of the Middle Dnieper area and its importance for the East-West correlation, Volume of Abstracts. IGS NASU, Kiev: 32-33.

Gozhik (Gozik), P.F., Matviishina, Zh., Gerasimenko, N., Rekovets, L., Shelkoplyas, V., 2001b. Quaternary stratigraphy. In: The Ukraine Quaternary explored: the Middle and Upper Pleistocene of the Middle Dnieper area and its importance for the East-West correlation, Volume of Abstracts. IGS NASU, Kiev: 8-11.

Gozhik (Gozik), P.F., Chlebowski, R., Lindner, L., 2001c. Pivikha Hill. In: The Ukraine Quaternary explored: the Middle and Upper Pleistocene of the Middle Dnieper area and its importance for the East-West correlation (ed. P.F. Gozhik (Gozik)):36-38. Excursion Guide. Institute of Geological Sciences NASU, Kyiv

Gozhik (Gozik), P.F., Matviishina, Zh., Gerasimenko, N., 2001d. Nahirne section. In: The Ukraine Quaternary explored: the Middle and Upper Pleistocene of the Middle Dnieper area and its importance for the East-West correlation. Excursion Guide. Institute of Geological Sciences NASU, Kyiv: 39-40.

Gozhik, P., Gerasimenko, N., Matviishina, Zh., Palienko, V., Korniets, N., Komar, M., Mel'nichuk, I., Perederiy, V., Rakovets, L., Shelkoplyas, V., Rousseau, D.D., Kukla, G., Velitchko, A., Gribchenko, Yu., Kurenkova, E., Novenko, E., Lindner, L., Chlebowski, R., 2001e. The Ukraine Quaternary explored: the Middle and Upper Pleistocene of the Middle Dnieper Area and its importance for the East-West correlation. Excursion Guide. IGS NASU: 62-62.

Gozhik, P., Komar, M., Krokhmal, O., Shelkoplyas (Shelkoplas), V., Khrystoforova, T., Dykan, N., Prylypko, S., 2007. Oporny rozriz neopleystocenovykh subaeralnykh vidkladiv bilya $\mathrm{s}$. Roksolany (Odeska oblast) (in Ukrainian with English summary). In: Problemy serednopleystocenoho interglacialu, Lviv, Vid (ed. A. Boguckyi): 109-128. Centr LNU.

Gozhik, P., Lindner, L., Marks, L., 2012. Late Early and early Pleistocene limits of Scandinavian glaciations in Poland and Ukraine. Quaternary Research, 271: 31-37.

Gozhik, P., Komar, M., Łanczont, M., Fedorowicz, S., Bogucki, A., Mroczek, P., Prylypko, S., Kusiak, J., 2014. Paleoenvironmental history of the Middle Dnieper Area from the Dnieper to Weichselian Glaciation: a case study of the Maksymivka loess profile. Quaternary International, 334-335: 94-111.

Grunty-Ukraina, 1:1 000 000, 1997 (Soils of Ukraine) (in Ukrainian). Naukovo-Vyrobnyche Pidpryemstvo Kartografija, Kiev.

Guiter, F., Andrieu-Ponel, V., De Beaulieu, J.L., Cheddadi, R., Calvez, M., Ponel, P., Reille, M., Keller, T., Goeury, C., 2003. The last climatic cycles in Western Europe: a comparison between long continuous lacustrine sequences from France and other terrestrial records. Quaternary International, 111: 59-74.

Kolstrup, E., 1994. Examples of Weichselian environments local versus regional developments. Eiszeitalter u. Gegenwart, 44: $16-19$ 
Komar, M., 2010. About location of possible Last Glaciation European trees refugia. Annual Meeting INQUA-SEQS "Quaternary stratigraphy and paleontology of the Southern Russia: connections between Europe, Africa and Asia", Abstract Volume, Rostov-On-Don: 76-76.

Komar, M., Krokhmal, O.I., Melnik, O.V., Prylypko, S.K., 2004. Complex investigations of the deposits of Andrusovka section (Kirovograd region, Ukraine). In: Reconstruction of Quaternary palaeoclimate and palaeoenvironments and their abrupt changes (eds. H. Winter and J. Przasnyska): 17-18. Abstracts and field trip guide-book, 22 September-2 October 2004, Białowie a, Poland. Państwowy Instytut Geologiczny, Warszawa

Komar, M., Krokhmal, A.I., Melnik, O.V., Prylypko, S.K., 2005. Neopleistocene deposits of Velyka Andrusivka profile (Middle Dnieper area, Ukraine) (in Ukrainian with English summary). Geological Journal, 2: 106-113.

Komar, M., Łanczont, M., Madeyska, T., 2009. Spatial vegetation patterns based on palynological records in the loess area between the Dnieper and Odra rivers during the last interglacial-glacial cycle. Quaternary International, 198: 152-172.

Komar, M., Gozhik (Go yk), P., Łanczont, M., Fedorowicz, S., Prylypko, S., Bogucki, A., Bluszcz, A., Adamiec, G., Moska, P., 2012. Ewolucja krajobrazów środkowego Dniepru i geochronologia etapów rozwoju roślinności i klimatu (na przykładzie reperowego profilu lessowego Maksymiwka, Ukraina) (in Polish). In: Korelacja osadów plejstocenu na pograniczu polskoniemieckim w dolinie dolnej Odry. XIX Konferencja Stratygrafia plejstocenu Polski (eds. M. Błaszkiewicz and F. Brose): 127-130. Cedynia, 3-7.09.2012. Państwowy Instytut Geologiczny.

Li, B., Kong, H., Sun, J., 2011. Isochron dating of sand-loess-soil deposits from the Mu Us Desert margin, central China. Quaternary Geochronology, 6: 556-563.

Lindner, L., Gozhik, P., Marciniak, B., Marks, L., Yelovicheva, J., 2004. Main climatic changes in the Quaternary of Poland, Belarus and Ukraine. Geological Quarterly, 48 (2): 97-114.

Lindner, L., Boguckyi, A., Gozhik, P., Marks, L., Łanczont, M., Wojtanowicz, J., 2006. Correlation of Pleistocene deposits in the area between the Baltic and Black Sea, Central Europe. Geological Quarterly, 50 (1): 195-210.

Łanczont, M., Gozhik, P., Fedorowicz, S., Bogucki, A., Komar, M., Bluszcz, A., Adamiec, G., Moska, P., Mroczek, P., 2013a. Profil lessowy Nahirne w dolinie środkowego Dniepru: aspekt stratygraficzny i paleogeograficzny (in Polish). In: VI Seminarium Geneza, litologia, stratygrafia utworów czwartorzędowych, SGP, Poznań: 100-104.

Łanczont, M., Madeyska, T., Bogucki, A., Sytnyk, O., Komar, M., Nawrocki, J., Kusiak, J., Frankowski, Z., ogała, B., 2013b. About the stratigraphical position and natural environment of the oldest Middle Palaeolithic in the central part of Podolia: new data from the Velykyi Glybochok site. Quaternary International, 326-327: 191-212.

Łanczont, M., Madeyska, T., Komar, M., Bogucki, A., 2014. The environments of loess uplands to the north and east of the Carpathians during the penultimate interglacial (MOIS 7) in palaeopedological and palaeobotanical records. European Journal of Soil Science, 65: 436-454.

Matoshko, A.V., 1999. Sedimentary model of the Staiky loess plateau, Prydniprovs'ka Upland, Ukraine. Geological Quarterly, 43 (2): 219-232.

Matoshko, A.V., 2004. Pleistocene glaciations in the Ukraine Developments in Quaternary Sciences. Quaternary Glaciations Extent and Chronology, 2: 431-440.
Matoshko, A.V., 2011a. Limits of the Pleistocene Glaciation in Ukraine: a closer look. Developments in Quaternary Sciences, 15: 405-418.

Matoshko, A.V., 2011b. The late Cenozoic continental development within the northern part of the Dnieper-Donets depression and adjacent structures. In: Quaternary studies in Ukraine to the XVIII Congress of the International Union for Quaternary research, Bern, Kyiv (eds. P.F. Gozhik, N.I. Dykan, V.M. Matviishina, V.M. Shelkoplayas and B.D. Vozgrin): 105-124.

Matoshko, A.V., Chugunny, Yu., G. 1993. Dneprovskoe olednenie teritorii Ukrainy (geologicheskij aspect) (in Russian). Naukova Dumka, Kiev.

Matviishina, Z.M., 1982. Mikromorfologia pleistocenovykh pochv Ukrainy (in Russian). Naukova Dumka, Kiev.

Mroczek, P., 2008. Palaeogeographic Interperation of micromorphological features of Neopleistocene loess-palaeosol sequences) (in Polish with English summary). Maria Curie-Skłodowska University Press, Lublin.

Mroczek, P., 2013. Recycled loesses a micromorphological approach to determination of local source areas of Weichselian loess. Quaternary International, 296: 241-250.

Putevoditel IX Pol'sko-Ukrainskogo polevogo seminara "Stratigrafiya i korrelatsiya lessov i lednikovykh otlozheniy Polshi i Ukrainy (in Russian), 1999, IGS NASU: 62-62.

Revised Standard Soil Color Charts, 1970. Fujihara Industry Company, Tokyo.

Ró ycki, S.Z., 1986. Loess type dust deposits in the world. Their distribution and origin (in Polish with English summary). Studia Geologica Polonica, 85.

Schmidt, E.D., Semmel, A., Frechen, M., 2011. Luminescence dating of the loess/palaeosol sequence at the gravel quarry Gaul/Weilbach, Southern Hesse (Germany). Quaternary Science Journal, 60: 116-125.

Shelkoplyas (Shelkoplas), V., 2001. Geochronology of geological events in the Quaternary period of Ukraine. In: The Ukraine Quaternary explored: the Middle and Upper Pleistocene of the Middle Dnieper Area and its importance for the East-West correlation. Volume of abstracts, Institute of Geological Sciences NASU, Kiev: 83-83.

Shelkoplyas, V.N., Khristophorova, T.F., 2005. K voprosu o stratigraphicheskom polozhenii kajdatskogo pochvennogo kompleksa (in Russian). Tektonika i Stratigrafiya, 34: 116-118.

Soil Atlas of Europe, 2005. European Commission. Directorate-General. Joint Researches Centre. European Soil Bureau Network.

Thompson, W.G., Goldstein, S.L., 2006. A radiometric calibration of the SPECMAP timescale. Quaternary Science Reviews, 25: 3207-3215.

Kocsis, K., Rudenko, L., Schweitzer, F. eds., 2008. Ukraine in Maps. Institute of Geography National Academy of Sciences of Ukraine, Geographical Research Institute Hungarian Academy Sciences, Kiev-Budapest.

Veklitch, M.F. ed., 1993. Stratigraficheskya shema chetvertichnykh otlozheniy Ukrainy (in Russian). Academy of Sciences of Ukraine, State Committee for Geology of Ukraine, Kiev.

Wintle, A., Prószyńska, H., 1983. TL dating of loess in Germany and Poland. PACT, 9: 547-554.

Wróbel, J., Mrugała, Sz., 2001. Charakterystyka klimatu (in Polish with English summary). Przegląd Geograficzny, 73: 389-414. 